\title{
Effects of size and origin of natural dissolved organic matter compounds on the redox cycling of iron in sunlit surface waters
}

\author{
Laurence Meunier, Hansulrich Laubscher, Stephan J. Hug and Barbara Sulzberger* \\ Swiss Federal Institute of Aquatic Science and Technology (Eawag), Ueberlandstrasse 133, \\ CH-8600 Duebendorf, Switzerland
}

Received: 7 December 2004; revised manuscript accepted: 18 April 2005

\begin{abstract}
The effects of size and origin of natural dissolved organic matter compounds (DOM) on the redox cycling of iron were investigated in water samples from a marine system (Strait of Gibraltar), from a freshwater system (Lake of Murten, i.e., Murtensee, Switzerland), and from a "river-to-ocean" system (Rivers Scheldt and Rhine and corresponding estuaries). In the irradiated seawater samples, Fe(II) steady-state concentrations ([Fe(II) $]_{\mathrm{ss}}$ ), both as percentage of total dissolved iron and normalized to $1 \mathrm{mg} \mathrm{C} \mathrm{L}{ }^{-1}$, were higher in the low-molecular-weight (LMW) than in the high-molecular-weight (HMW) DOM fractions, despite higher net rates of $\mathrm{H}_{2} \mathrm{O}_{2}$ formation in the HMW DOM fractions. Also in the samples from Murtensee, $[\mathrm{Fe}(\mathrm{II})]_{\mathrm{ss}}$, both as percentage of total dissolved iron and normalized to the decadic absorption coefficient at $350 \mathrm{~nm}\left(\alpha_{350}\right.$, unit $\left.\mathrm{m}^{-1}\right)$, were higher in the LMW than in the HMW DOM fractions. Unlike in the seawater sam-
\end{abstract}

ples, however, net rates of $\mathrm{H}_{2} \mathrm{O}_{2}$ production, normalized to $\alpha_{350}$, were higher in the LMW DOM fractions, as compared to the HMW DOM fractions, indicating a higher efficiency of $\mathrm{O}_{2}^{--}$formation with these LMW compounds from Murtensee. Based on the simulation of experimental data with mathematical kinetic modeling, we hypothesize that $\mathrm{Fe}$ (II) is formed through photolysis of $\mathrm{Fe}$ (III) complexes in the LMW DOM fractions from the Strait of Gibraltar and from Murtensee and that $\mathrm{Fe}(\mathrm{II})$ is stabilized by a ligand in the water samples from Murtensee. In the irradiated HMW DOM fractions from the "river-toocean" system, [Fe(II)] $]_{\mathrm{ss}}$, normalized to $\alpha_{350}$, were generally higher in the water samples from the Rivers Scheldt and Rhine than in the water samples from their estuaries, suggesting that terrestrially derived DOM has a higher photochemical reactivity towards $\mathrm{Fe}$ (II) formation than autochthonous DOM.

Key words. Iron photochemistry; DOM photochemistry; iron(III) reduction; iron(II) stabilization; iron(II) oxidation; kinetic modeling.

\section{Introduction}

Iron is an essential micronutrient for almost all organisms. In cells iron can exist in more than one oxidation state, and catalysis of redox reactions and electron transport are two major functions of iron containing enzymes.

* Corresponding author phone: +41 1823 5459; fax: +41 1823 5028; e-mail: sulzberger@eawag.ch Published Online First: August 29, 2005
Iron is present in the active centers of cytochromes and iron-sulfur proteins, e.g., ferrodoxin, which are important components of the photosynthetic and respiratory electron transport chain (e.g., Butler, 1998; Falkowski, 1997; Sunda, 1991). Iron has been proposed to co-limit phytoplankton growth in several marine environments (e.g., Mills et al., 2004; Morel and Price, 2003; Schulz et al., 2004).

The biological availability of iron depends on its speciation and on the uptake mechanism by organisms. An- 
derson and Morel (1982) have proposed a carrier-mediated transport model of iron uptake by eukariotic marine algae. According to this model, the concentration of inorganic, dissolved $\mathrm{Fe}$ (III) species (including the hydrated and hydrolyzed ions) determines the upper limit of bioavailable iron. Most ( $>99 \%$ ) of the dissolved ferric iron is present as organic iron complexes in marine surface waters (e.g., Powell and Donat, 2001; Rue and Bruland, 1995; Rue and Bruland, 1997; van den Berg, 1995; Wu and Luther, 1995) and probably also in rivers and lakes. In sunlit surface waters, inorganic $\mathrm{Fe}(\mathrm{III})$ species are formed through light-induced redox cycling of iron (e.g., Powell and Wilson-Finelli, 2003).

Iron(II) is a key intermediate species, regarding both iron bioavailability and the roles of $\mathrm{Fe}(\mathrm{II})$ as reducing agent. For example, $\mathrm{Fe}(\mathrm{II})$ has been shown to act as the electron donor in $\mathrm{Cr}(\mathrm{VI})$ reduction (Gaberell et al., 2003; Hug et al., 1997; Kieber and Helz, 1992) (see Fig. 1). Furthermore, $\mathrm{Fe}(\mathrm{II})$ catalyzes the reductive dissolution of Fe(III)-(hydr)oxides (Siffert and Sulzberger, 1991; Suter et al., 1988) and acts as an electron donor in the reductive dissolution of $\mathrm{MnO}_{2}$ (Villinski et al., 2003). As a result of $\mathrm{Fe}$ (II)-promoted dissolution of minerals, adsorbed organic and inorganic compounds, e.g., organic pollutants and phosphate, are remobilized. Oxidation of $\mathrm{Fe}$ (II) by $\mathrm{O}_{2}$ yields the reactive oxygen species (ROS) $\mathrm{O}_{2}^{-}, \mathrm{H}_{2} \mathrm{O}_{2}$, and $\mathrm{HO}^{*}$, where the latter is formed in the Fenton reaction (Fe(II) $+\mathrm{H}_{2} \mathrm{O}_{2} \rightarrow \mathrm{Fe}(\mathrm{III})+\mathrm{HO}^{*}+\mathrm{OH}^{-}$) (see Fig. 1). The Fenton reaction can be an important source of $\mathrm{HO}^{*}$ in iron-rich, sunlit surface waters (Southworth and Voelker, 2003; White et al., 2003), and $\mathrm{HO}^{*}$ is the most reactive oxygen species (Blough and Zepp, 1995), reacting efficiently with organic and inorganic pollutants and with cell components of aquatic organisms (see Fig. 1).

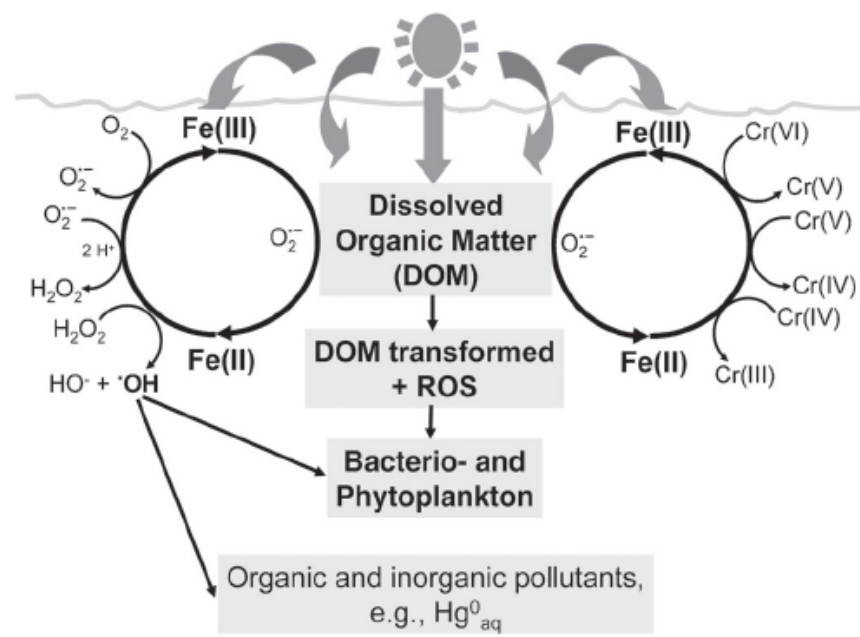

Figure 1. Schematic representation of environmentally important processes that are linked to the light-induced redox cycling of iron in sunlit surface waters (see text). ROS stands for Reactive Oxygen Species, e.g., $\mathrm{HO}^{*}, \mathrm{O}_{2}^{-}$, and $\mathrm{H}_{2} \mathrm{O}_{2}$.

\section{Background}

Roles of natural organic compounds in the light-induced reduction of dissolved $\mathrm{Fe}(\mathrm{III})$. In sunlit surface waters, formation of $\mathrm{Fe}$ (II) can proceed through the following abiotic pathways: (i) Photolysis of Fe(III) complexes (e.g., Barbeau et al., 2001; Barbeau et al., 2003; Barbeau et al., 2002; Faust and Zepp, 1993; Gao and Zepp, 1998; Kuma et al., 1992; Voelker et al., 1997), (ii) reduction of Fe(III) by $\mathrm{O}_{2}^{-}$(e.g., Emmenegger et al., 2001; Miller et al., 1995; Rose and Waite, 2003a; Rose and Waite, 2005; Voelker and Sedlak, 1995), and (iii) thermal reduction of Fe(III) by natural organic compounds (e.g., Voelker et al., 1997; Voelker and Sulzberger, 1996). In addition, Fe(III) also may be reduced at the surface of algal cell, which is a strategy of some algae to utilize iron bound to organic ligands (e.g., Hutchins et al., 1999; Jones et al., 1987; Maldonado and Price, 1999; Maldonado and Price, 2001; Soria-Dengg and Horstmann, 1995; Weger, 1999; Weger et al., 2002). Regarding the bioavailability of these organic $\mathrm{Fe}(\mathrm{III})$ complexes to aquatic microorganisms, Hutchins et al. (1999) suggested that the competition between prokaryotes and eukaryotes for organically-bound iron may depend on the chemical nature of iron complexes, where iron bound to a variety of siderophores was relatively more available to cyanobacteria than to eukaryotes. In pathways (i)-(iii), natural organic compounds act as electron donors. Hitherto, we are lacking a clear picture of the relative importance of above pathways in the formation of $\mathrm{Fe}(\mathrm{II})$ in sunlit marine and freshwater systems.

Photolysis of $\mathrm{Fe}$ (III) complexes (pathway (i)) may involve siderophores (Barbeau et al., 2001; Barbeau et al., 2003; Barbeau et al., 2002) or other natural Fe(III) ligands (Faust and Zepp, 1993; Gao and Zepp, 1998; Kuma et al., 1992; Voelker et al., 1997). Siderophores are low-molecular-weight organic ligands $(0.5-1.5 \mathrm{kDa})$ with a high affinity and specificity for iron. Under iron-limiting conditions, siderophores are excreted by cyano- and heterotrophic bacteria (e.g., Haygood et al., 1993; Reid and Butler, 1991; Tortell et al., 1999; Wilhelm and Trick, 1994). The stability constants of $\mathrm{Fe}$ (III)-siderophore complexes are in the range of $\log \mathrm{K}=20-50$ (Albrecht-Gary and Crumbliss, 1998; Witter et al., 2000). Photolysis of Fe(III) siderophore complexes has been demonstrated with the siderophores petrobactin and aerobactin (Barbeau et al., 2003; Barbeau et al., 2002; Borer et al., 2005), and various aquachelins (Barbeau et al., 2001). The photoreactivity of these Fe(III)siderophore complexes is imparted by the $\alpha$-hydroxycarboxylate functional group, which decarboxylates following ligand-to-metal charge-transfer transition. According to recent studies of the photochemical reactivity of siderophores based on characteristic iron(III)-binding groups, siderophores containing only hydroxamate groups such as DFOB form photostable complexes with Fe(III) (Barbeau et al., 2003; Borer et al., 2005). 
Roles of natural organic compounds in the oxidation of $\mathrm{Fe}(\mathrm{II})$. Natural organic compounds also may greatly affect the kinetics of Fe(II) oxidation. Several investigators observed an acceleration of the $\mathrm{Fe}(\mathrm{II})$ oxidation by $\mathrm{O}_{2}$ in the presence of natural organic compounds such as fulvic acid (Liang et al., 1993; Pullin and Cabaniss, 2003; Rose and Waite, 2002) or the siderophore DFOB (Welch et al., 2002). Santana-Casiano and coworkers (2004) studied the oxidation of $\mathrm{Fe}$ (II) in $\mathrm{NaCl}-\mathrm{HCO}_{3}^{-}$and seawater solutions in the presence of phthalate and salicylate ions. Phthalate decreased the Fe(II) oxidation rate, while salicylate increased it. Emmenegger and coworkers (1998) assessed the apparent rate constant, $\mathrm{k}_{\mathrm{app}}$, of $\mathrm{Fe}$ (II) oxidation as a function of $\mathrm{pH}$ in unfiltered lake water samples, to which Fe(II) was added to give an initial Fe(II) concentration of $30 \mathrm{nM}$. Above $\mathrm{pH} 7.4, \mathrm{k}_{\mathrm{app}}$ was consistent with the rate law determined in pure carbonate systems. However, below this $\mathrm{pH}$ value, $\mathrm{k}_{\text {app }}$ was independent of $\mathrm{pH}$. These authors explain this phenomenon in terms of acceleration of $\mathrm{Fe}(\mathrm{II})$ oxidation by ligands (organic, colloidal, or surface ligands) below pH 7.4. Also the Fenton reaction is greatly affected by natural organic compounds. Sedlak and Hoigné (1993) and Voelker and Sulzberger (1996) have shown that $\mathrm{H}_{2} \mathrm{O}_{2}$ reacts much faster with $\mathrm{Fe}(\mathrm{II})$-oxalate and $\mathrm{Fe}(\mathrm{II})$-fulvate complexes than with inorganic Fe(II). Voelker and Sulzberger (1996) also found an enhancing effect of fulvic acid on the Fenton reaction through the following reaction sequence: (i) scavenging of the $\mathrm{HO}^{\circ}$ radical formed in the Fenton reaction by fulvic acid, yielding an organic radical, (ii) reaction of this organic radical with $\mathrm{O}_{2}$ to form $\mathrm{HO}_{2}^{*} / \mathrm{O}_{2}^{*-}$, (iii) regeneration of $\mathrm{H}_{2} \mathrm{O}_{2}$ by reaction of $\mathrm{HO}_{2}^{\circ} / \mathrm{O}_{2}^{--}$with $\mathrm{Fe}(\mathrm{II})$.

Natural organic compounds also may result in a decrease of Fe(II) oxidation rates. Theis and Singer (1974) and Miles and Brezonik (1981) reported that a variety of model Fe(II)-binding ligands and humic acids decreased the rate of $\mathrm{Fe}$ (II) oxidation by $\mathrm{O}_{2}$. When assessing the $\mathrm{Fe}(\mathrm{II})$ oxidation kinetics, one has to be aware that net rates are determined, which include the rate of $\mathrm{Fe}(\mathrm{II})$ oxidation and the rate of re-reduction of Fe(III). Ferric iron may be reduced thermally, e.g., by fulvic acid (Voelker and Sulzberger, 1996). Furthermore, $\mathrm{HO}_{2}^{*} / \mathrm{O}_{2}^{-}$formed in the oxidation of $\mathrm{Fe}(\mathrm{II})$ by $\mathrm{O}_{2}$ acts as an electron donor of $\mathrm{Fe}(\mathrm{III})$. Finally, Fe(II) may be stabilized by organic ligands (Suzuki et al., 1992). In most studies regarding Fe(II) oxidation kinetics, Fe(II) is added to synthetic or natural water samples (e.g., Emmenegger et al., 1998). As a result, some effects of natural organic compounds, e.g., stabilization of $\mathrm{Fe}(\mathrm{II})$, may not be apparent because of much lower concentrations of these natural organic ligands, as compared to added Fe(II). The effects of the source and concentration of natural organic matter (NOM) on the $\mathrm{Fe}(\mathrm{II})$ oxidation kinetics was investigated by Rose and Waite (2003b). These authors reported that increasing the concentration of NOM enhanced the degree of acceleration or retardation of $\mathrm{Fe}(\mathrm{II})$ oxidation, depending on the source of NOM.

\section{Objectives}

As discussed above, Fe(II) is a key intermediate species in sunlit surface waters, regarding both iron bioavailability and its role as an electron donor in many environmentally relevant processes. Therefore, it is important to elucidate the roles of natural organic compounds (in the following abbreviated as DOM, Dissolved Organic Matter) in the formation and consumption of Fe(II). As will be demonstrated, both the size and the origin of DOM affect to a great extent $\mathrm{Fe}$ (II) steady-state concentrations in sunlit surface waters. The objectives of this study were (i) to assess the effect of the size of dissolved organic matter compounds on $\mathrm{Fe}$ (II) steady-state concentrations, (ii) to test hypotheses on the pathway of light-induced Fe(III) reduction and the kinetics of $\mathrm{Fe}(\mathrm{II})$ oxidation by simulating experimental data (measured $\mathrm{Fe}(\mathrm{II})$ and $\mathrm{H}_{2} \mathrm{O}_{2}$ concentrations during irradiation and after the light-source was turned off) with mathematical kinetic modeling, and (iii) to assess possible effects of the DOM origin on the lightinduced redox cycling of iron.

\section{Materials and methods}

\section{Study sites and sample collection}

Seawater was sampled at different sites in the Strait of Gibraltar (sites P1-P5, Fig. 2A and Table 1) during a cruise on the Dutch research vessel Pelagia (Royal NIOZ) between May 26 and June 4, 2001. At the sampling location $35^{\circ} 6^{\prime} \mathrm{N}, 5^{\circ} 5^{\prime} \mathrm{W}$, Mediterranean Sea water is covered by water from the Atlantic Ocean, and hence the water sample from this site, collected at $5 \mathrm{~m}$ depth (P4), was an Atlantic seawater sample, whereas all the other water samples were Mediterranean seawater samples. Water samples from different depths were collected using a CTD rosette equipped with Go-Flow bottles, which were coated with a thin film of Teflon. Immediately after collection, the water samples were passed on board through $0.22 \mu \mathrm{m}$ GUPP-C cassette filters $\left(0.5 \mathrm{~m}^{2}\right)$ mounted on a Pellicon holder (Millipore), followed by size fractionation of DOM (see below). All sampling and filtration devices were metal clean.

Freshwater samples were collected in Murtensee, a lake located in the western part of Switzerland (Fig. 2B). Its surface area is $22.8 \mathrm{~km}^{2}$, and its average depth is $23.3 \mathrm{~m}$, with a maximal depth of $45.5 \mathrm{~m}$. Intensive agricultural activities cause eutrophic conditions in this lake. On October 24, 2002, the dissolved organic carbon concentration (DOC) was $\sim 290 \mu \mathrm{M}$ (Table 1). Water samples were collected on October 24, 2002, offshore of the city of Murten and at the location where the lake was deepest, 


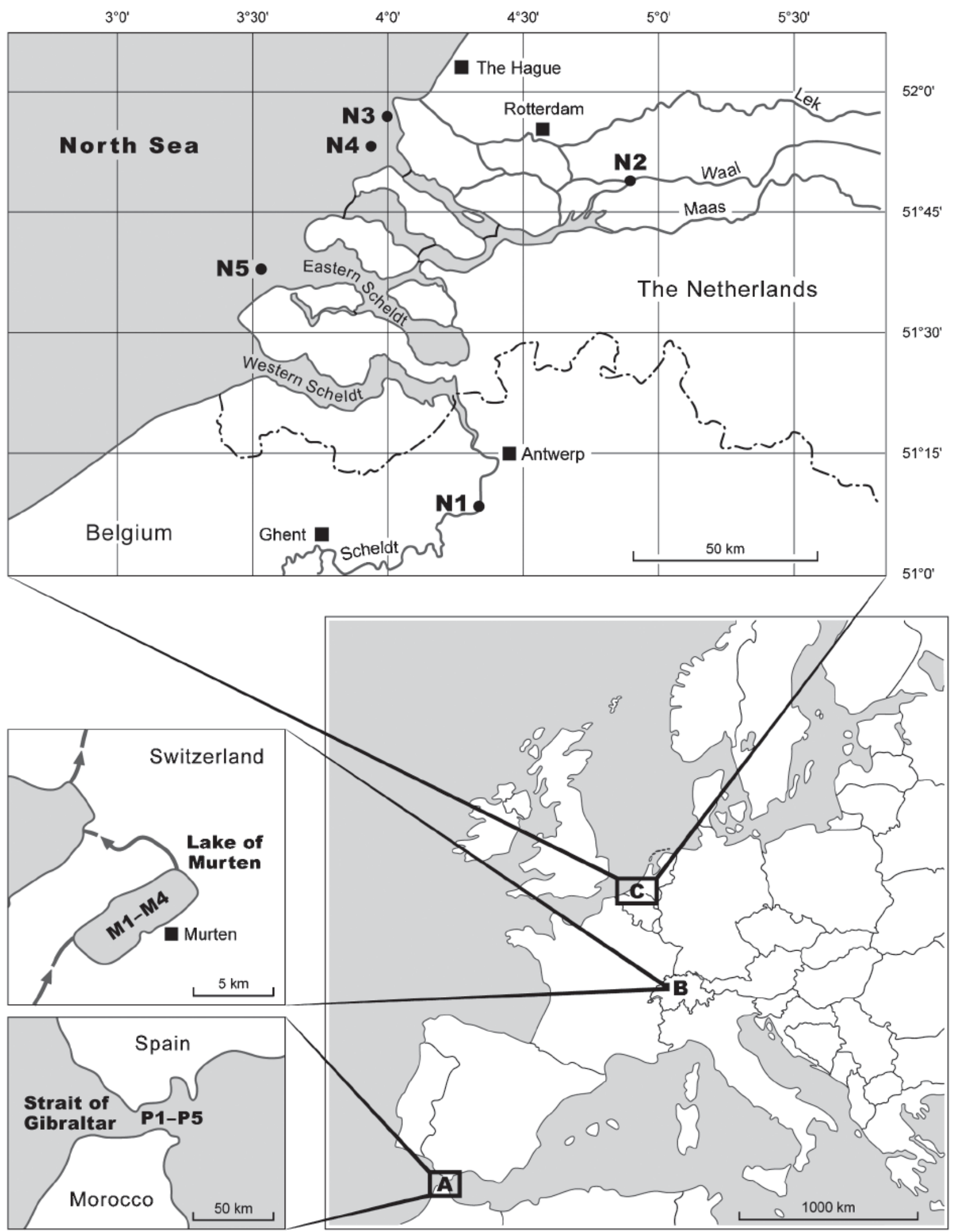

Figure 2. Map of Western Europe with the study areas. Water samples were collected at different locations and depths in the Strait of Gibraltar (sites P1-P5, Map A), in Murtensee (Switzerland) (sites M1-M4, Map B), and in a river-to-ocean system (sites N1-N5, Map C). 
Table 1. Salinity and concentration of dissolved organic carbon (DOC) at the sites where water samples were collected during the Pelagia-Cruise (May 2001), in Murtensee (October 2002), and during the Navicula-Cruise (April 2001).

\begin{tabular}{|c|c|c|c|}
\hline $\begin{array}{l}\text { Designation } \\
\text { of site }\end{array}$ & Location/depth & $\begin{array}{l}\text { Salinity } \\
(\% 0)\end{array}$ & $\begin{array}{l}\text { DOC } \\
(\mu \mathrm{M})^{\mathrm{a}}\end{array}$ \\
\hline & Pelagia-Cruise & & \\
\hline P1 & $37^{\circ} 9^{\prime} \mathrm{N}, 0^{\circ} 6^{\prime} \mathrm{W} / \quad 5 \mathrm{~m}$ & 38.5 & 76.6 \\
\hline P2 & $37^{\circ} 9^{\prime} \mathrm{N}, 0^{\circ} 6^{\prime} \mathrm{W} / 40 \mathrm{~m}$ & 38.5 & 74.1 \\
\hline P3 & $36^{\circ} 2^{\prime} \mathrm{N}, 3^{\circ} 5^{\prime} \mathrm{W} / 150 \mathrm{~m}$ & 38.5 & 58.3 \\
\hline $\mathrm{P} 4^{\mathrm{b}}$ & $35^{\circ} 6^{\prime} \mathrm{N}, 5^{\circ} 5^{\prime} \mathrm{W} / \quad 5 \mathrm{~m}$ & 36.5 & 70.8 \\
\hline \multirow[t]{2}{*}{ P5 } & $38^{\circ} 2^{\prime} \mathrm{N}, 9^{\circ} 5^{\prime} \mathrm{W} / 350 \mathrm{~m}$ & 38.5 & 72.4 \\
\hline & Murtensee & & \\
\hline $\mathrm{M}^{\mathrm{c}}$ & Surface $(<1 \mathrm{~m})$ & 0 & 314.7 \\
\hline $\mathrm{M} 2^{\mathrm{c}}$ & $6 \mathrm{~m}$ & 0 & 299.7 \\
\hline $\mathrm{M}^{\mathrm{d}}$ & Surface $(<1 \mathrm{~m})$ & 0 & 270.6 \\
\hline \multirow[t]{2}{*}{$\mathrm{M}^{\mathrm{d}}$} & $6 \mathrm{~m}$ & 0 & 284.7 \\
\hline & Navicula-Cruise & & \\
\hline $\mathrm{N} 1^{\mathrm{e}}$ & River Scheldt & 0 & 601.3 \\
\hline $\mathrm{N} 2^{\mathrm{e}}$ & River Rhine/Waal & 0 & 251.2 \\
\hline $\mathrm{N} 3^{\mathrm{e}}$ & $\begin{array}{l}\text { River Rhine/ } \\
\text { Alter Wasserweg }\end{array}$ & 9.6 & 257.7 \\
\hline $\mathrm{N} 4^{\mathrm{e}}$ & North Sea & 25.5 & 167.0 \\
\hline $\mathrm{N} 5^{\mathrm{e}}$ & North Sea & 30.0 & 158.6 \\
\hline
\end{tabular}

a In filtered water samples $(<0.22 \mu \mathrm{m}$ for samples from site P1-P5, and $<0.45 \mu \mathrm{m}$ for samples from M1-M4 and N1-N5).

b At this site, Mediterranean Sea water is covered by water from the Atlantic Ocean.

c Water samples were taken in the middle of Murtensee.

${ }^{d}$ Water samples were taken offshore of the city of Murten.

e For the geographical location of the sites N1-N5, see Figure 2C. Samples were taken at the surface $(<1 \mathrm{~m})$.

both at the surface and at $6 \mathrm{~m}$ depth (sites M1-M4, see Table 1). The sampling was performed by use of Go-Flow bottles. The water samples were brought back to the laboratory at Eawag in Duebendorf, passed through $0.45 \mu \mathrm{m}$ cellulose nitrate filters (Sartorius), followed by DOM size fractionation (see below) within 48 hours. All sampling and filtration devices were metal clean.

Water samples with different salinity were collected during a cruise with the Dutch research vessel Navicula (Royal NIOZ) between April 2 and April 12, 2001 in the River Scheldt (site N1), the River Waal (site N2), outside the River Rhine delta (sites N3 and N4), and outside the Eastern Scheldt esturary (site N5) (Fig. 2C and Table 1). The River Scheldt originates in the North of France and flows across Belgium and The Netherlands into the North Sea forming the Western and Eastern Scheldt estuaries (Fig. 2C). The River Scheldt is one of the most contaminated rivers in Europe (Somville and Depauw, 1982) with an extremely high DOC content (Table 1). Indeed, the River Scheldt catchment presently receives sewage discharge with only partial treatment from cities such as Lille, Antwerp, Brussels, and Ghent. The River Waal is one branch of the River Rhine, which originates in the Swiss Alps and which splits into two branches (Lek and
Waal) on its flow through The Netherlands. The Rivers Lek, Waal, and Maas form a huge river delta in The Netherlands (Fig. 2C). Water was sampled with a fish (a Teflon sampling bag attached to a lead weight, looking like a fish), passed through $0.2 \mu \mathrm{m}$ polycarbonate filters $(\mathrm{Nu}-$ cleopore) immediately after sampling, followed by DOM size fractionation on board (see below). All sampling and filtration devices were metal clean.

\section{Materials}

$\mathrm{NaCl}$ (suprapure quality), $\mathrm{HCl}$ (30\%, suprapure quality), $\mathrm{HNO}_{3}\left(65 \%\right.$, suprapure quality), $\mathrm{NH}_{3}(25 \%$, suprapure quality), hydrogen peroxide (30\%, suprapure quality), potassium bromate (pro analysis quality), 3-[4-(2-hydroxyethyl)-1-piperazinyl] propanesulfonic acid (HEPPS) (purity, 99\%), 1-nitroso-2-naphtol (pro analysis quality), methanol (pro analysis quality) were purchased from Merck, Germany. 5-amino-2,3-dihydrophtalazine-1,4-dion (luminol), p-hydroxyphenylacetic acid (puriss p.a. grade), ammonium ferrous sulfate hexahydrate (puriss p.a. grade) ferric chloride hexahydrate (puriss p.a. grade) were provided by Fluka, Switzerland. Peroxidase, 10,000 U, grade II, from horseradish (HRP) was from Roche Diagnostics Gmbh, Germany.

All solutions were prepared with MQ-UV water (Millipore). Water samples and reagents were prepared and stored in polypropylene bottles. These bottles as well as the Pyrex glass vessels, used in the photochemical experiments (see below), were cleaned according to the following protocol: first they were soaked over night in a detergent solution, then rinsed with MQ-UV water, soaked for at least 3 days in $0.1 \mathrm{M} \mathrm{HCl}$ and thereafter for a least 3 days in $0.1 \mathrm{M} \mathrm{HNO}_{3}$. Finally they were rinsed with MQ-UV water, dried and stored in plastic bags until use. Glassware for DOC measurement was soaked for at least 3 days in $0.1 \mathrm{M} \mathrm{HCl}$, rinsed with MQ-UV water, and muffled $5 \mathrm{~h}$ at temperatures $>500^{\circ} \mathrm{C}$ to eliminate all organic substances.

\section{DOM fractionation}

DOM in water samples from sites P1-P5 and M1-M4 was size fractionated employing a Pellicon tangential flow ultrafiltration system (Millipore) with a $0.5 \mathrm{~m}^{2}$ PLAC cassette filter (Millipore) (1 kDa nominal weight cutoff) and following the protocol by Benner et al. (1997). We operationally define the fraction with $\mathrm{DOM}<1 \mathrm{kDa}$ as low-molecular-weight (LMW) DOM in all water samples, and the fraction with $1 \mathrm{kDa}<\mathrm{DOM}<0.22 \mu \mathrm{m}$ and $1 \mathrm{kDa}<\mathrm{DOM}<0.45 \mu \mathrm{m}$ as high-molecular-weight (HMW) DOM in water samples from sites P1-P5 and sites M1-M4, respectively. The concentrates and permeates were deep-frozen immediately after ultrafiltration until use. 
DOM in water samples from sites $\mathrm{N} 1-\mathrm{N} 5$ was size fractionated using an Amicon DC-10 or an Amicon Proflux M 30 system with two spiral-wound polysulfone filter cartridges (S10N1, $1 \mathrm{kDa}$ nominal weight cutoff). To gain a powdery product, the water content of the concentrates was reduced by rotary evaporation, and the samples were dried in a Savant SVC200 SpeedVac concentrator. The powders obtained were stored in precombusted glass vials until further use.

\section{Determination of DOC concentrations}

For the determination of DOC concentrations in the 0.22 $\mu \mathrm{m}$ and $0.45 \mu \mathrm{m}$ filtered water samples from sites P1-P5 and M1-M4, respectively, and in corresponding concentrates and permeates, $20 \mathrm{ml}$ of each solution were placed into acid-rinsed, precombusted 40-ml EPA glass vials, immediately after filtration and ultrafiltration, sealed with Teflon-lined caps and stored frozen until analysis. For the determination of DOC concentrations in the HMW DOM fraction of waters samples from sites N1-N5, part of each powder was dissolved in MQ-UV water, considering the concentration factor. DOC concentrations were determined by high-temperature catalytic oxidation with a Shimadzu 5050A analyzer (Benner et al., 1997; Benner and Strom, 1993). For the water samples from sites P1P5 and M1- M4, a carbon mass balance was established to determine whether carbon was lost or gained during size fractionation. Mass balance calculations yielded recoveries of $120-155 \%$ for the water samples from sites P1-P5 and $87-120 \%$ for the water samples from sites M1-M4. This percentage of DOC recovered after ultrafiltration was calculated as follows: $\%$ DOC recovered $=100$ $\times\left(\mathrm{DOC}_{\text {concentrate }}+\mathrm{DOC}_{\text {permeate }}\right) \times\left(\mathrm{DOC}_{<0.22 / 0.45 \mathrm{\mu m}}\right)^{-1}$, where DOC stands for the DOC concentration, $\mathrm{DOC}_{\text {concentrate }}$ for DOC in the HMW DOM fraction, corrected by the according concentration factor, $\mathrm{DOC}_{\text {permeate }}$ for $\mathrm{DOC}$ in the LMW DOM fraction, and $\mathrm{DOC}_{<0.22 / 0.45 \mathrm{\mu m}}$ for DOC in the DOM fraction that passed a $0.22 \mu \mathrm{m}$ or $0.45 \mu \mathrm{m}$ filter (used for water samples from sites P1-P5 or M1-M4, respectively). The fact that more than $100 \%$ of DOC was recovered by ultrafiltration was likely due to contamination from the ultrafiltration membrane, which consisted of regenerated cellulose. Although this membrane was thoroughly cleaned according to the protocol by Benner et al. (1997) before ultrafiltration of the various water samples, it was not possible to avoid some carbon leaching, as has been observed by other investigators using the same ultrafiltration membrane (e.g., Kaiser and Sulzberger, 2004).

\section{Determination of total dissolved iron concentrations}

For the determination of total dissolved iron concentrations in the HMW and LMW DOM fractions, concen- trates and permeates were collected in metal clean 50-ml (samples from sites P1-P5) and 10-ml (samples from sites M1-M4) PP tubes (Greiner), immediately following ultrafiltration. After acidification to $\mathrm{pH} \sim 2$, the samples were kept deep-frozen until analysis. To determine total dissolved iron concentrations in the HMW DOM fractions of waters samples from sites N1-N5, part of each powder was dissolved in MQ-UV water, considering the concentration factor.

Total dissolved iron concentrations in the HMW and LMW DOM fractions of water samples from sites P1-P5 were measured employing catalytic cathodic stripping voltammetry (674 VA Stand and 646 VA processor, Metrohm), following the protocol by Aldrich and van den Berg (1998). 1-nitroso-2-naphtol was used to form a complex with $\mathrm{Fe}(\mathrm{III})$ that adsorbs on a static mercury drop electrode, and $\mathrm{BrO}_{3}^{-}$was used to oxidize $\mathrm{Fe}(\mathrm{II})$, eventually present in the water samples. Measurements were performed at $\mathrm{pH}$ 7.7, using HEPPS buffer. Prior to measurements, samples were irradiated for $24 \mathrm{~h}$ with a $\mathrm{Hg}$ lamp (La Jolla Scientific Co.) at $\mathrm{pH} 2$ to eliminate dissolved organic matter. Blanks (MQ-UV water) were treated in the same way as the samples. The detection limit of this analytical method was $0.5 \mathrm{nM}$.

Total dissolved iron concentrations in the HMW and LMW DOM fractions of water samples from sites M1M4 and N1-N5 were detected using a Perkin-Elmer 5100 GF-AAS with a transverse heated graphite tube atomizer (THGA). Dissolved iron in the LMW DOM fractions was pre-concentrated three times by injecting $50 \mathrm{ml}$ of the samples and drying for $50 \mathrm{~s}$ at $130^{\circ} \mathrm{C}$. The detection limit was $2 \mathrm{nM}$ for the pre-concentrated samples.

\section{Other methods}

$\mathrm{pH}$ measurements were made by use of an Orion Ross electrode and an Orion meter calibrated with NBS buffers. Buffers and samples were kept at $25^{\circ} \mathrm{C}$ unless stated otherwise. Alkalinity was determined by automated Grantitration with use of a Mettler DL 70 ES titrator. UV/VIS spectra were recorded in a quartz cell of $5 \mathrm{~cm}$ optical path length using a Varian Cary 1E UV/VIS spectrophotometer.

\section{Photochemical experiments}

For the photochemical experiments, the concentrates of the water samples from sites P1-P5 and M1-M4 were diluted with MQ-UV water by the concentration factor, and part of the HMW DOM powders gained from the water samples from sites N1-N5 were dissolved in MQUV water to yield a DOC concentration of approximately $2 \mathrm{mg} \mathrm{L}{ }^{-1}$. A pH of 8.2 was established by bubbling a mixture of $\mathrm{CO}_{2}, \mathrm{~N}_{2}$, and $20.9 \% \mathrm{O}_{2}$ through the solutions. $300 \mathrm{ml}$ of each solution were filled into a water-jacketed 
reactor with an optical Pyrex bottom and irradiated with a 1000-W Xe lamp (OSRAM), contained in a watercooled housing (PTI, 02-A50001), and simulating solar radiation. The light was focused by two Pyrex lenses (50\% cutoff at $335 \mathrm{~nm}$ ) and a mirror onto the bottom of the reaction vessel. A more detailed description of the experimental setup is given in Siffert and Sulzberger (1991). We measured the average incident light intensity hitting the bottom of the reaction vessel through a narrowband filter (UV1, $\lambda_{\max } 355 \mathrm{~nm}$ ), using ferrioxalate actinometry (Hatchard and Parker, 1956). The total light intensity hitting the vessel, when the light was not filtered by the narrowband filter, was calculated from the photon flux of the filtered light, the transmission spectrum of the filters and the bottom of the vessel, and the spectrum of the unfiltered light. The incident light intensity was approximately $0.5,1.0$, and $1.2 \mathrm{~kW} \mathrm{~m}^{-2}$ in the photochemical experiments with the water samples from sites P1-P5, M1-M4, and $\mathrm{N} 1-\mathrm{N} 5$, respectively. In all photochemical experiments the solutions were air-saturated and continuously stirred, and the temperature $\left(20^{\circ} \mathrm{C}\right)$ and $\mathrm{pH}(8.2-8.3)$ were kept constant.

Iron(II) and $\mathrm{H}_{2} \mathrm{O}_{2}$ concentrations were measured during irradiation and after the light source was turned off. For the determination of $\mathrm{Fe}(\mathrm{II})$ concentrations, we employed a flow injection analysis system with luminol-based chemiluminescence detection (FeLume) (Emmenegger et al., 1998; Emmenegger et al., 2001; King et al., 1995). An alkaline luminol solution is mixed with the water sample containing $\mathrm{Fe}$ (II) in front of a photomultiplier. At pH 9.8, $\mathrm{Fe}(\mathrm{II})$ is oxidized by molecular oxygen on a millisecond timescale, catalyzing the oxidation of luminol resulting in its electronic excitation that deactivates by producing blue chemiluminescence light. Calibration curves were established after each photochemical experiment in the identical water matrix. Iron(II) was added from an acid (pH 2) stock solution containing $1 \mu \mathrm{M} \mathrm{Fe}($ II). This stock solution was prepared daily from another stock solution containing $100 \mu \mathrm{M}$ Fe(II) at $\mathrm{pH} 2$, which was prepared twice a month. Both stock solutions were kept at $4^{\circ} \mathrm{C}$. The detection limit was usually $0.2 \mathrm{nM} \mathrm{Fe(II).}$

For measuring $\mathrm{H}_{2} \mathrm{O}_{2}$ concentrations, we used the method by Miller and Kester (1988), modified by Emmenegger et al. (2001), utilizing a Perkin-Elmer LS-3 fluorescence spectrophotometer. We checked that the potential light-induced production of organic peroxides did not influence the $\mathrm{H}_{2} \mathrm{O}_{2}$ fluorescence measurements (data not shown).

\section{Kinetic modeling}

For the mathematical simulation of the time courses of $\mathrm{Fe}$ (II) and $\mathrm{H}_{2} \mathrm{O}_{2}$ during irradiation and after the light source was turned off, we used the program ACUCHEM (Braun et al., 1988). This program can calculate the con- centrations of reactants versus time in a complex chemical system by finding a numerical solution to the system of nonlinear differential equations defined by the kinetics problem. Best fits of kinetic constants, which were not accessible experimentally or whose values could not be taken from the literature, were obtained by combining ACUCHEM with a Matlab program (The Math Works, Inc., Natick, MA 01760). The unknown rate constants were varied until the sum of squared residuals between the measured data points and the model was minimized. To give $\mathrm{Fe}(\mathrm{II})$ and $\mathrm{H}_{2} \mathrm{O}_{2}$ the same statistical weight, their maximum concentrations were normalized to 1 for the fitting. The optimization routine was the Nelder-Mead simplex (direct search) method of Matlab.

\section{Results and discussion}

\section{Effect of the size of natural organic compounds on $\mathrm{Fe}$ (II) steady-state concentrations}

Considerably higher percentages of Fe(II) steady-state concentrations $\left([\mathrm{Fe}(\mathrm{II})]_{\mathrm{ss}}\right.$ ) from total dissolved iron (water samples filtered through $0.22 \mu \mathrm{m}$ filters) were found upon irradiation of low-molecular-weight (LMW) DOM, as compared to high-molecular-weight (HMW) DOM in water samples from the Strait of Gibraltar (Fig. 3A). Hence the total dissolved iron concentration is not the major factor determining $\left([\mathrm{Fe}(\mathrm{II})]_{\mathrm{ss}}\right.$ in these DOM fractions. This phenomenon was also observed by Gaberell and coworkers (2003), who studied the role of dissolved organic matter composition on the photoreduction of $\mathrm{Cr}(\mathrm{VI})$ to $\mathrm{Cr}(\mathrm{III})$ in the presence of iron. Also $[\mathrm{Fe}(\mathrm{II})]_{\mathrm{ss}}$, normalized to $1 \mathrm{mg} \mathrm{C} \mathrm{L}^{-1}$, were higher in the LMW than in the HMW DOM fractions (Fig. 3B). Regarding $\mathrm{H}_{2} \mathrm{O}_{2}$ formation, the net rate, normalized to $1 \mathrm{mg} \mathrm{C} \mathrm{L}^{-1}$ was higher in the HMW fractions than in the LMW fractions. The fact that higher $[\mathrm{Fe}(\mathrm{II})]_{\mathrm{ss}}$ occurred with LMW DOM, as compared to HMW DOM, despite higher net rates of $\mathrm{H}_{2} \mathrm{O}_{2}$ formation with HMW DOM lead us to the following hypothesis: The main pathway of $\mathrm{Fe}(\mathrm{III})$ reduction in these water samples is photolysis of Fe(III) complexes (and not reduction of $\mathrm{Fe}(\mathrm{III})$ by $\mathrm{O}_{2}^{--}$) and occurs more readily if $\mathrm{Fe}(\mathrm{III})$ is bound to LMW organic ligands, as compared to HMW ligands. This hypothesis is tested experimentally in ongoing studies.

Also in the freshwater samples from Murtensee, both the percentage of $[\mathrm{Fe}(\mathrm{II})]_{\mathrm{ss}}$ from total dissolved iron (water samples filtered through $0.45 \mu \mathrm{m}$ filters) and $[\mathrm{Fe}(\mathrm{II})]_{\mathrm{ss}}$, normalized to $1 \mathrm{mg} \mathrm{C} \mathrm{L}^{-1}$, were higher in the LMW DOM fractions than in the HMW DOM fractions (Figs. 4A and B), and approximately five times higher than in the seawater LMW DOM fractions, if normalized to equal light intensities (note that the light intensity of the solar simulator was approximately two times higher in the experiments with the freshwater samples, see "Materials 

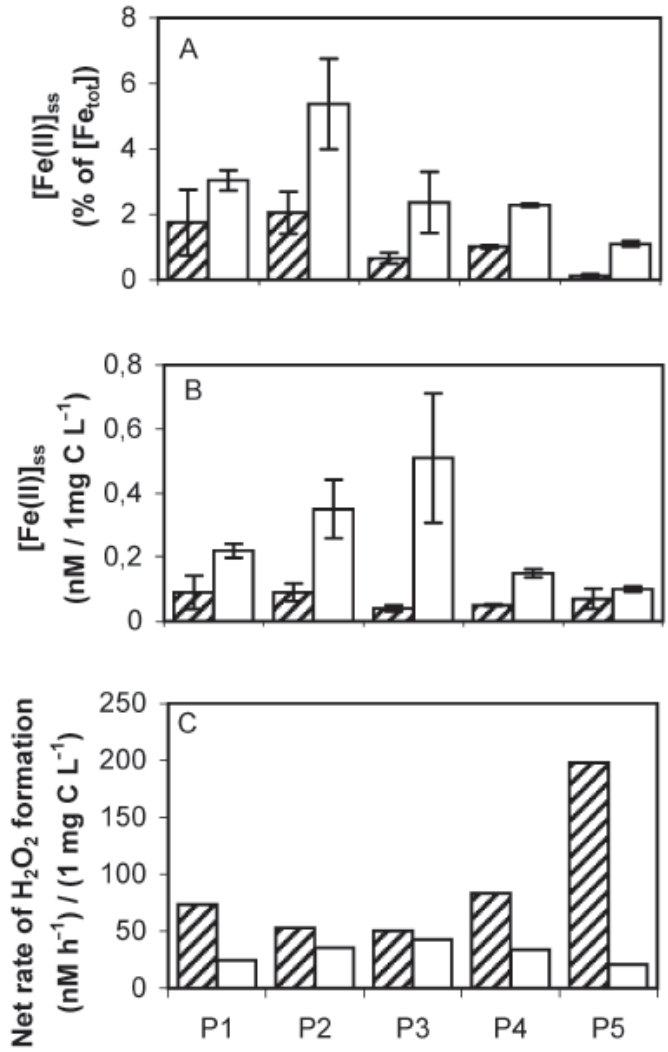

Sampling sites

Figure 3. Steady-state concentrations of $\mathrm{Fe}$ (II) as the percentage of total dissolved iron (A) and normalized to $1 \mathrm{mg} \mathrm{C} \mathrm{L}^{-1}(\mathrm{~B})$, and net rate of $\mathrm{H}_{2} \mathrm{O}_{2}$ formation, normalized to $1 \mathrm{mg} \mathrm{C} \mathrm{L}^{-1}(\mathrm{C})$, during irradiation with simulated sunlight $\left(\mathrm{I}_{0} \sim 0.5 \mathrm{~kW} \mathrm{~m}^{-2}\right)$ of HMW DOM (shaded bars) and LMW DOM (open bars) $(\mathrm{pH}=8.2-8.3)$ from sites P1-P5. The HMW DOM fractions were diluted by the concentration factors for the photochemical experiments (see Materials and methods section). Data represent the mean of 2-3 measurements; vertical bars indicate the mean deviation.

and methods"). If [ $\mathrm{Fe}(\mathrm{II})]_{\mathrm{ss}}$ is divided by the decadic absorption coefficient at $350 \mathrm{~nm}\left(\alpha_{350}\right.$, unit $\left.\mathrm{m}^{-1}\right)$ the difference between LMW and HMW DOM fractions is even more pronounced in the water samples from Murtensee (Fig. 4C). These results suggest that the efficiency of Fe(II) formation is higher with LMW DOM than with HMW DOM from Murtensee. Regarding photochemical $\mathrm{H}_{2} \mathrm{O}_{2}$ formation, its net rate was higher in the LMW DOM fractions than in the HMW DOM fractions, particularly if divided by $\alpha_{350}$ (Figs. 4D and E). [Note that the rate of $\mathrm{H}_{2} \mathrm{O}_{2}$ formation, divided by $\alpha_{350}$, can be considered as a relative quantum yield of $\mathrm{H}_{2} \mathrm{O}_{2}$ formation at respective wavelength.] This surprising result means that LMW DOM from Murtensee is photochemically more reactive than HMW DOM from this freshwater system. A higher photoreactivity of LMW DOM, as compared to HMW DOM, in terms of $\mathrm{H}_{2} \mathrm{O}_{2}$ formation also was observed by Kaiser and Sulzberger (2004) with water samples from
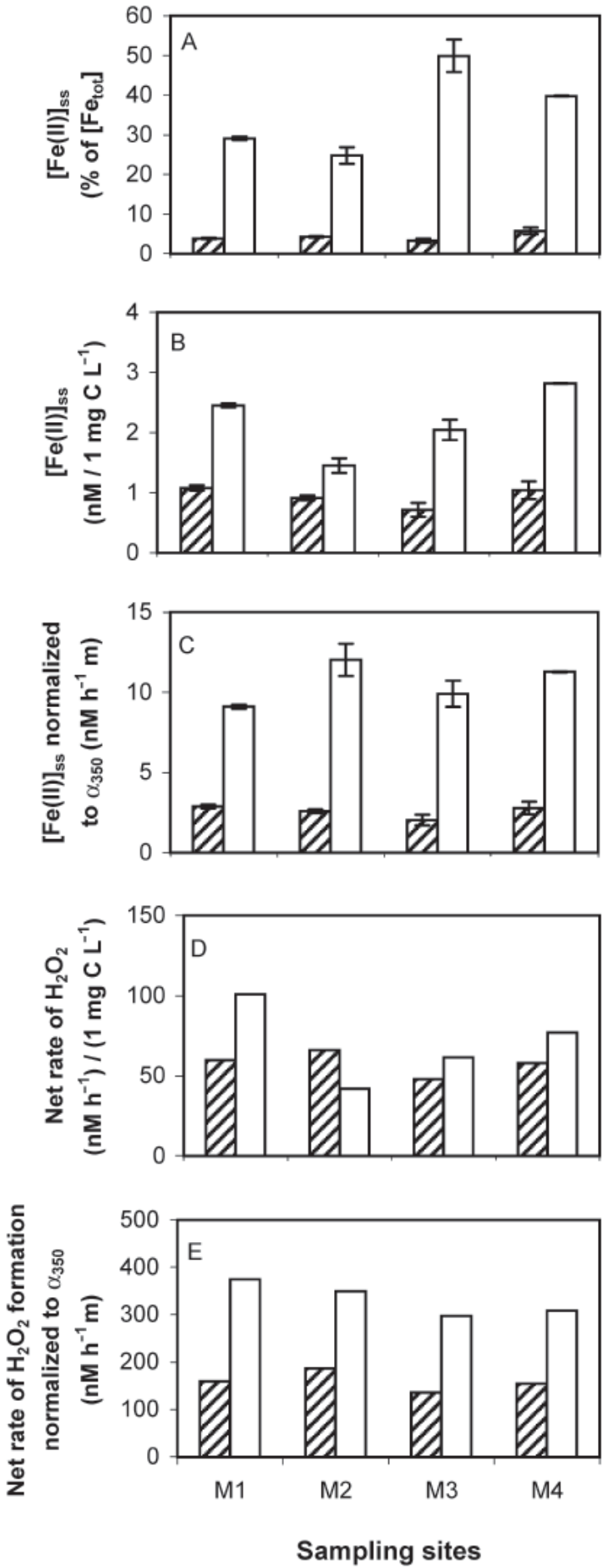

Figure 4. Steady-state concentrations of $\mathrm{Fe}$ (II) as percentage of total dissolved iron (A), normalized to $1 \mathrm{mg} \mathrm{C} \mathrm{L}^{-1}(\mathrm{~B})$, and normalized to $\alpha_{350}(\mathrm{C})$ during irradiation with simulated sunlight $\left(\mathrm{I}_{0} \sim 1.0\right.$

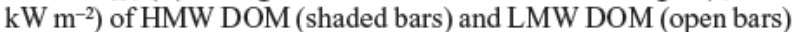
$(\mathrm{pH}=8.2)$ from sites $\mathrm{M} 1-\mathrm{M} 4$. The two lower panels of this figure show net rates of $\mathrm{H}_{2} \mathrm{O}_{2}$ formation, normalized to $1 \mathrm{mg} \mathrm{C} \mathrm{L}^{-1}$ (D) and to $\alpha_{350}$ (E) during irradiation with simulated sunlight $\left(\mathrm{I}_{0} \sim 1.0 \mathrm{~kW}\right.$ $\mathrm{m}^{-2}$ ) of HMW DOM (shaded bars) and LMW DOM (open bars) from sites M1-M4. The HMW DOM fractions were diluted by the concentration factors for the photochemical experiments (see Materials and methods section). Data represent the mean of 2-3 measurements; vertical bars indicate the mean deviation. 
the Tagliamento River (Italy). These authors also assessed the effect of light on DOM bioavailability to bacterioplankton from the Tagliamento River and found that after the long-term growth of bacteria on irradiated DOM, the uptake was unchanged for HMW DOM, however, considerably lower for LMW DOM, compared with the corresponding non-irradiated fractions. Kaiser and Sulzberger (2004) hypothesize that as a consequence of the higher photoreactivity of LMW compounds from the Tagliamento, these compounds are transformed into highly biorecalcitrant compounds upon irradiation. Powell and Wilson-Finelli (2003) reported that photodegradation of ligands occurred in a ligand class that was less than $1 \mathrm{kDa}$ in size and ubiquitous throughout the Gulf of Mexico and hypothesized that release of siderophores may be the dominant production term for these ligands.

\section{Kinetics of $\mathrm{Fe}(\mathrm{II})$ and $\mathrm{H}_{2} \mathrm{O}_{2}$ formation and decay}

Figure 5 shows the measured concentrations of $\mathrm{Fe}$ (II) and $\mathrm{H}_{2} \mathrm{O}_{2}$ during irradiation and after the light source was turned off (symbols) with the LMW DOM fraction of the water sample from site P3 (see Table 1). The Fe(II) concentration reached steady-state after ca. 4 min of irradiation and decreased to zero within ca. $10 \mathrm{~min}$ after the light source was turned off. The $\mathrm{H}_{2} \mathrm{O}_{2}$ concentration increased linearly and did not reach steady-state during irradiation. After the light source was turned off, the $\mathrm{H}_{2} \mathrm{O}_{2}$ concentration remained constant for hours (data not shown). This kinetic behavior of the $\mathrm{Fe}(\mathrm{II})$ and $\mathrm{H}_{2} \mathrm{O}_{2}$ concentrations was generally observed with both the LMW and HMW DOM fractions from the Strait of Gibraltar. Totally different behaviour was observed with the LMW and HMW DOM fractions from Murtensee, e.g., with the LMW fraction of the water sample from site M4 (Fig. 6). In this case, the $\mathrm{Fe}(\mathrm{II})$ concentration reached

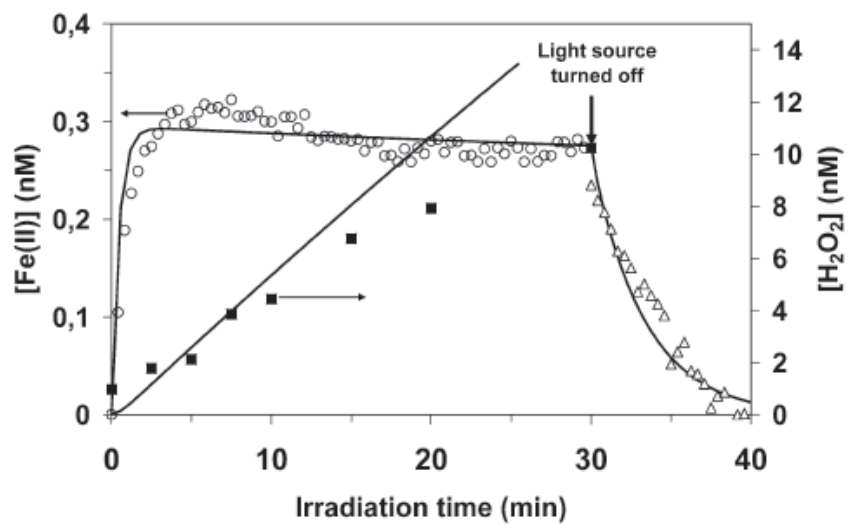

Figure 5. Experimental data (symbols) and modeling results (solid lines) of the concentrations of $\mathrm{Fe}(\mathrm{II})$ and $\mathrm{H}_{2} \mathrm{O}_{2}$ during and after irradiation with simulated sunlight $\left(\mathrm{I}_{0} \sim 0.5 \mathrm{~kW} \mathrm{~m}^{-2}\right)$ of LMW DOM $(\mathrm{pH}=8.3)$ from site $\mathrm{P} 3$.

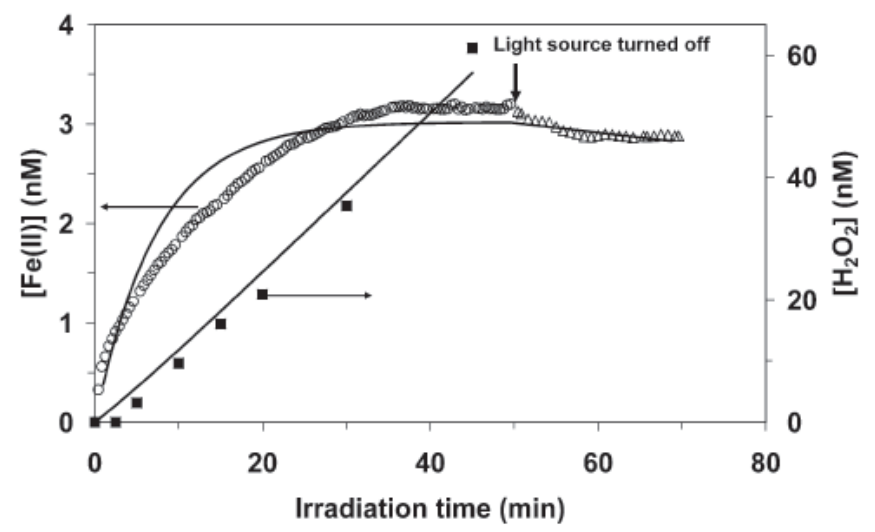

Figure 6. Experimental data (symbols) and modeling results (solid lines) of the concentrations of $\mathrm{Fe}$ (II) and $\mathrm{H}_{2} \mathrm{O}_{2}$ during and after irradiation with simulated sunlight $\left(\mathrm{I}_{0} \sim 1.0 \mathrm{~kW} \mathrm{~m}^{-2}\right)$ of LMW DOM $(\mathrm{pH}=8.2)$ from site $\mathrm{M} 4$.

steady-state only after approximately $35 \mathrm{~min}$, and only a slight decrease in the $\mathrm{Fe}(\mathrm{II})$ concentration was observed after the light source was turned off in the time frame of the experiment. With respect to $\mathrm{H}_{2} \mathrm{O}_{2}$, its concentration increased linearly without reaching steady-state during irradiation (Fig. 6).

As discussed in the "Introduction", various phenomena may account for a slow decay of the Fe(II) concentration after irradiation of water samples. Emmenegger and coworkers (2001) observed a slow decay of the $\mathrm{Fe}(\mathrm{II})$ concentration in whole water samples from the Lake of Greifen (Switzerland), although less pronounced than in the present study. Based on mathematical kinetic modeling, these authors hypothesized that this slow decay is due to recycling of $\mathrm{Fe}$ (II) by $\mathrm{O}_{2}^{--}$. Another possibility is stabilization of $\mathrm{Fe}(\mathrm{II})$ by organic ligands. To evaluate this possibility and to test our hypothesis that photolysis of $\mathrm{Fe}$ (III) complexes is the main pathway of $\mathrm{Fe}(\mathrm{II})$ formation in the LMW DOM samples from the Strait of Gibraltar and from Murtensee, we simulated the experimental data shown in Figures 5 and 6 using a kinetic model. The rate constants and rates of considered reactions, and the equilibrium constant of formation of an $\mathrm{Fe}$ (II) complex with the ligand $\mathrm{L}$ are listed in Table 2. [Note that the symbol L is used in the text and in Table 2 exclusively to denote the $\mathrm{Fe}(\mathrm{II})$-stabilizing ligand; other ligands present in the water samples are not specified, and organic $\mathrm{Fe}(\mathrm{III})$ complexes are designed as "Fe(III)", see also below]. The values denoted as "fp" are the optimized rate constants that provided best fits (see also Fig. 7), the other values were taken from the literature or were estimated based on literature values.

The rate constant of photolysis of $\mathrm{Fe}$ (III) complexes (reaction 1) was assumed to be in the range suggested by Miller and coworkers (1995). The rate of photochemical production of $\mathrm{O}_{2}^{--}$involving CDOM (reaction 2) is not known and was a fitting parameter in our model. Further- 
Table 2. Reactions and kinetic parameters used in the kinetic model.

\begin{tabular}{|c|c|c|c|c|}
\hline No. & Equation & $\begin{array}{l}\text { Kinetic parameters for } \\
\text { the LMW DOM sample } \\
\text { from site P3 } \\
\text { (Strait of Gibraltar) }\end{array}$ & $\begin{array}{l}\text { Kinetic parameters for } \\
\text { the LMW DOM sample } \\
\text { from site M4 } \\
\text { (Murtensee) }\end{array}$ & References \\
\hline $1^{\mathrm{a}}$ & $\mathrm{Fe}(\mathrm{III})+\mathrm{h} v \rightarrow \mathrm{Fe}(\mathrm{II})+$ products & $\mathrm{k}=0.001 \mathrm{~s}^{-1}$ & $\mathrm{k}=0.001 \mathrm{~s}^{-1}$ & \multirow[t]{2}{*}{ Miller et al. (1995) ${ }^{\mathrm{b}}$} \\
\hline $\begin{array}{l}2^{c} \\
3\end{array}$ & $\begin{array}{l}\mathrm{CDOM} \stackrel{\mathrm{O}_{2}, \mathrm{~h} v}{\longrightarrow} \mathrm{CDOM}^{{ }^{+}}+\mathrm{O}_{2-}^{--} \\
\mathrm{Fe}(\mathrm{III})+\mathrm{O}_{2}^{--} \rightarrow \mathrm{Fe}(\mathrm{II})+\mathrm{O}_{2}\end{array}$ & $\begin{array}{l}\mathrm{r}=9.5 \times 10^{-10} \mathrm{M} \mathrm{s}^{-1}(\mathrm{fp} 1)^{\mathrm{c}} \\
\mathrm{k}=<10^{4} \mathrm{M}^{-1} \mathrm{~s}^{-1}(\mathrm{fp} 2)\end{array}$ & $\begin{array}{l}\mathrm{r}=9.9 \times 10^{-8} \mathrm{M} \mathrm{s}^{-1}(\mathrm{fp} 1)^{\mathrm{c}} \\
\mathrm{k}=<10^{3} \mathrm{M}^{-1} \mathrm{~s}^{-1}(\mathrm{fp} 2)\end{array}$ & \\
\hline $\begin{array}{l}4 \\
5\end{array}$ & $\begin{array}{l}\mathrm{Fe}(\mathrm{II})+\mathrm{O}_{2} \rightarrow \mathrm{Fe}(\mathrm{III})+\mathrm{O}_{2}^{-} \\
\mathrm{Fe}^{\mathrm{II}} \mathrm{L}+\mathrm{O}_{2} \rightarrow \mathrm{Fe}^{\mathrm{III}} \mathrm{L}+\mathrm{O}_{2}^{-}\end{array}$ & $\begin{array}{l}\mathrm{k}=6.37 \mathrm{M}^{-1} \mathrm{~s}^{-1} \\
\mathrm{k}=10.4 \mathrm{M}^{-1} \mathrm{~s}^{-1}(\mathrm{fp} 3)\end{array}$ & $\begin{array}{l}\mathrm{k}=20.78 \mathrm{M}^{-1} \mathrm{~s}^{-1} \\
\mathrm{k}=0.21 \mathrm{M}^{-1} \mathrm{~s}^{-1}(\mathrm{fp} 3)\end{array}$ & King $(1998)^{d}$ \\
\hline $\begin{array}{l}6 \\
7\end{array}$ & $\begin{array}{l}\mathrm{Fe}(\mathrm{II})+\mathrm{O}_{2}^{-}+2 \mathrm{H}^{+} \rightarrow \mathrm{Fe}(\mathrm{III})+\mathrm{H}_{2} \mathrm{O}_{2} \\
\mathrm{Fe}^{\mathrm{II}} \mathrm{L}+\mathrm{O}_{2}^{--}+2 \mathrm{H}^{+} \rightarrow \mathrm{Fe}^{\mathrm{III}} \mathrm{L}+\mathrm{H}_{2} \mathrm{O}_{2}\end{array}$ & $\begin{array}{l}\mathrm{k}=1.00 \times 10^{7} \mathrm{M}^{-1} \mathrm{~s}^{-1} \\
\mathrm{k}=4.0 \times 10^{7} \mathrm{M}^{-1} \mathrm{~s}^{-1}(\mathrm{fp} 4)\end{array}$ & $\begin{array}{l}\mathrm{k}=1.00 \times 10^{7} \mathrm{M}^{-1} \mathrm{~s}^{-1} \\
\mathrm{k}=5.6 \times 10^{4} \mathrm{M}^{-1} \mathrm{~s}^{-1}(\mathrm{fp} 4)\end{array}$ & Rush and Bielski (1985) ${ }^{\mathrm{e}}$ \\
\hline 8 & $\mathrm{Fe}(\mathrm{II})+\mathrm{H}_{2} \mathrm{O}_{2} \rightarrow \mathrm{Fe}(\mathrm{III})+\mathrm{HO}^{*}+\mathrm{HO}^{-}$ & $\mathrm{k}=1.04 \times 10^{5} \mathrm{M}^{-1} \mathrm{~s}^{-1}$ & $\mathrm{k}=7.86 \times 10^{4} \mathrm{M}^{-1} \mathrm{~s}^{-1}$ & \multirow[t]{3}{*}{ King and Farlow $(2000)^{\mathrm{f}}$} \\
\hline 9 & $\mathrm{Fe}^{\mathrm{II}} \mathrm{L}+\mathrm{H}_{2} \mathrm{O}_{2} \rightarrow \mathrm{Fe}^{\mathrm{III}} \mathrm{L}+\mathrm{HO}^{-}+\mathrm{HO}^{-}$ & $\mathrm{k}=1.6 \times 10^{5} \mathrm{M}^{-1} \mathrm{~s}^{-1}(\mathrm{fp} 5)$ & $\mathrm{k}=<10^{2} \mathrm{M}^{-1} \mathrm{~s}^{-1}(\mathrm{fp} 5)$ & \\
\hline 10 & $\mathrm{Fe}^{\mathrm{III}} \mathrm{L} \rightarrow \mathrm{Fe}(\mathrm{III})+\mathrm{L}$ & $\mathrm{k}=1.00 \times 10^{10} \mathrm{M}^{-1} \mathrm{~s}^{-1}$ & $\mathrm{k}=1.00 \times 10^{10} \mathrm{M}^{-1} \mathrm{~s}^{-1}$ & \\
\hline 11 & $\mathrm{O}_{2}^{--}+\mathrm{O}_{2}^{--}+2 \mathrm{H}^{+} \rightarrow \mathrm{H}_{2} \mathrm{O}_{2}+\mathrm{O}_{2}$ & $\mathrm{k}=2.51 \times 10^{4} \mathrm{M}^{-1} \mathrm{~s}^{-1}$ & $\mathrm{k}=3.98 \times 10^{4} \mathrm{M}^{-1} \mathrm{~s}^{-1}$ & \multirow{3}{*}{$\begin{array}{l}\text { Zafiriou }(1990)^{\mathrm{g}} \\
\text { Estimated from Voelker } \\
\text { et al. }(2000) \text { and Goldstone } \\
\text { and Voelker }(2000)^{\mathrm{h}}\end{array}$} \\
\hline 12 & $\mathrm{O}_{2}^{-}+$sinks $\rightarrow$ products & $\mathrm{k}=1.16 \mathrm{~s}^{-1}$ & $\mathrm{k}=4.63 \mathrm{~s}^{-1}$ & \\
\hline $13^{\mathrm{i}}$ & $\mathrm{Fe}^{2+}+\mathrm{L} \Leftrightarrow \mathrm{Fe}^{\mathrm{II}} \mathrm{L}$ & $\mathrm{K}=>10^{8} \mathrm{M}^{-1}(\mathrm{fp} 6)$ & $\mathrm{K}=>10^{10} \mathrm{M}^{-1}(\mathrm{fp} 6)$ & \\
\hline
\end{tabular}

$\mathrm{fp}=$ fitting parameter, see also Figure 7.

${ }^{a} \mathrm{Fe}(\mathrm{III})$ stands for total dissolved Fe(III) in the P3 and M4 LMW DOM samples, whose initial concentration was $10.6 \mathrm{nM}$ and $6.8 \mathrm{nM}$, respectively.

b We assumed a rate constants of photolysis of Fe(III) complexes in the range of that suggested by Miller et al. (1995).

${ }^{c}[\mathrm{CDOM}]=27 \mu \mathrm{M}$ and $52 \mu \mathrm{M}$ in the P3 and M4 LMW DOM samples, respectively, based on measured DOC concentrations and assuming that $\sim 65 \%$ of DOC is colored. The rate, $r$, of superoxide formation includes the CDOM concentration, $r=k \times[C D O M]$, where $\mathrm{k}$ is equal to $\mathrm{fp} 1$ in Figure 7.

${ }^{\mathrm{d}}$ Rate constants given by King (1998) for $\mathrm{I}=0$, corrected for $\mathrm{I}=0.7 \mathrm{M}$ and $7 \mathrm{mM}$ for the P3 and M4 LMW DOM samples, respectively, using Debye Hückel. P3 LMW DOM sample: alkalinity $=2.4 \mathrm{mM}, \mathrm{pH}=8.3$; M4 LMW DOM sample: alkalinity $=3.4 \mathrm{mM}, \mathrm{pH}=8.2$.

${ }^{\mathrm{e}}$ For inorganic, dissolved $\mathrm{Fe}(\mathrm{II})$ at $\mathrm{pH}>6$.

${ }^{\mathrm{f}}$ Rate constants given by King and Farlow (2000) for I $=0$, corrected for I $=0.7 \mathrm{M}$ and $7 \mathrm{mM}$ for the P3 and M4 LMW DOM samples, respectively, using Debye Hückel. P3 LMW DOM sample: alkalinity $=2.4 \mathrm{mM}, \mathrm{pH}=8.3$; M4 LMW DOM sample: alkalinity $=3.4 \mathrm{mM}$, $\mathrm{pH}=8.2$. Regarding $\mathrm{HO}^{\circ}$ as a potential oxidant of $\mathrm{Fe}(\mathrm{II})$, we have neglected this pathway in these water samples on the basis of a study by Emmenegger et al. (1998). We also have neglected the possibility that products of reactions of HO* with other water components, e.g., $\mathrm{CO}_{3}^{2-}$, might - directly or indirectly - affect the iron redox cycling.

$\mathrm{g}$ This rate constant was calculated according to Zafiriou (1990) as follows: logk $=12.7-1.0(\mathrm{pH})$, with $\mathrm{pH}=8.3$ (P3 LMW DOM samples) and $\mathrm{pH}=8.2$ (M4 LMW DOM sample).

h These rate constants for reaction of superoxide with additional sinks are rough estimates based on Table 1 in Voelker et al. (2000) and Figure 2 in Goldstone and Voelker (2000) (see text).

${ }^{i}$ In Acuchem, this equilibrium is formulated as a forward reaction with an adjustable rate constant and a fast back reaction with $\mathrm{k}_{\mathrm{b}}=10^{8}$ $\mathrm{s}^{-1}$. The concentration of $\mathrm{L}$ is assumed to be $1 \mu \mathrm{M}$.

more, we assumed that $>99 \%$ of dissolved Fe(III) was present as organic $\mathrm{Fe}(\mathrm{III})$ complexes in the LMW DOM samples from sites $\mathrm{P} 3$ and $\mathrm{M} 4$. The rate constant of reaction of $\mathrm{O}_{2}^{--}$with organic $\mathrm{Fe}$ (III) species (reaction 3) also was a fitting parameter. Regarding the oxidation of $\mathrm{Fe}(\mathrm{II})$ by $\mathrm{O}_{2}$ and $\mathrm{H}_{2} \mathrm{O}_{2}$ (reactions 4 and 8 , respectively), we estimated these rate constants for the $\mathrm{pH}$ and the alkalinity of the LMW DOM samples from sites P3 and M4, based on the values given by King (1998) and King and Farlow (2000), respectively, for inorganic Fe(II) species.

We introduced an $\mathrm{Fe}(\mathrm{II})$ stabilizing ligand $\mathrm{L}$ in our model and unknown rate constants for the oxidation of $\mathrm{Fe}^{\mathrm{II}} \mathrm{L}$ by $\mathrm{O}_{2}, \mathrm{O}_{2}^{--}$, and $\mathrm{H}_{2} \mathrm{O}_{2}$ (reactions 5, 7, and 9). We assumed that $\mathrm{Fe}^{2 \mathrm{III}} \mathrm{L}$ undergoes fast ligand exchange with organic ligands present in the P3 and M4 LMW DOM samples that form more stable complexes with $\mathrm{Fe}(\mathrm{III})$ than does $\mathrm{L}$ (reaction 10, note that in our model, $\mathrm{L}$ is a Fe(II) stabilizing ligand.) Regarding sinks of $\mathrm{O}_{2}^{+-}$other than reaction with iron (reactions 3,6 , and 7), we included reactions of $\mathrm{O}_{2}^{--}$with dissolved copper (Voelker et al., 2000; Zafiriou et al., 1998) and with colored dissolved organic matter (CDOM) (Goldstone and Voelker, 2000) (summarized in reaction 12). To obtain an estimate for $\mathrm{k}_{12}$, we assumed that the major part of dissolved copper was present as organic $\mathrm{Cu}$ (II) complexes in these water samples (e.g., Bruland et al., 2000; van den Berg, 1984; Voelker and Kogut, 2001). The overall rate constant, $\mathrm{k}_{12}$, of reaction of $\mathrm{O}_{2}^{--}$with dissolved, organic $\mathrm{Cu}$ and $\mathrm{CDOM}$ was estimated based on the studies by Voelker et al. (2000) and Goldstone and Voelker (2000), where $\mathrm{k}_{12}=\mathrm{k}_{\mathrm{cat}}\left[\mathrm{Cu}_{\mathrm{tot}}\right]+$ $\mathrm{k}_{\text {other }}$ (Voelker et al., 2000). We assumed a value of $5.5 \times$ $10^{8} \mathrm{M}^{-1} \mathrm{~s}^{-1}$ for the rate constant of catalytic dismutation 

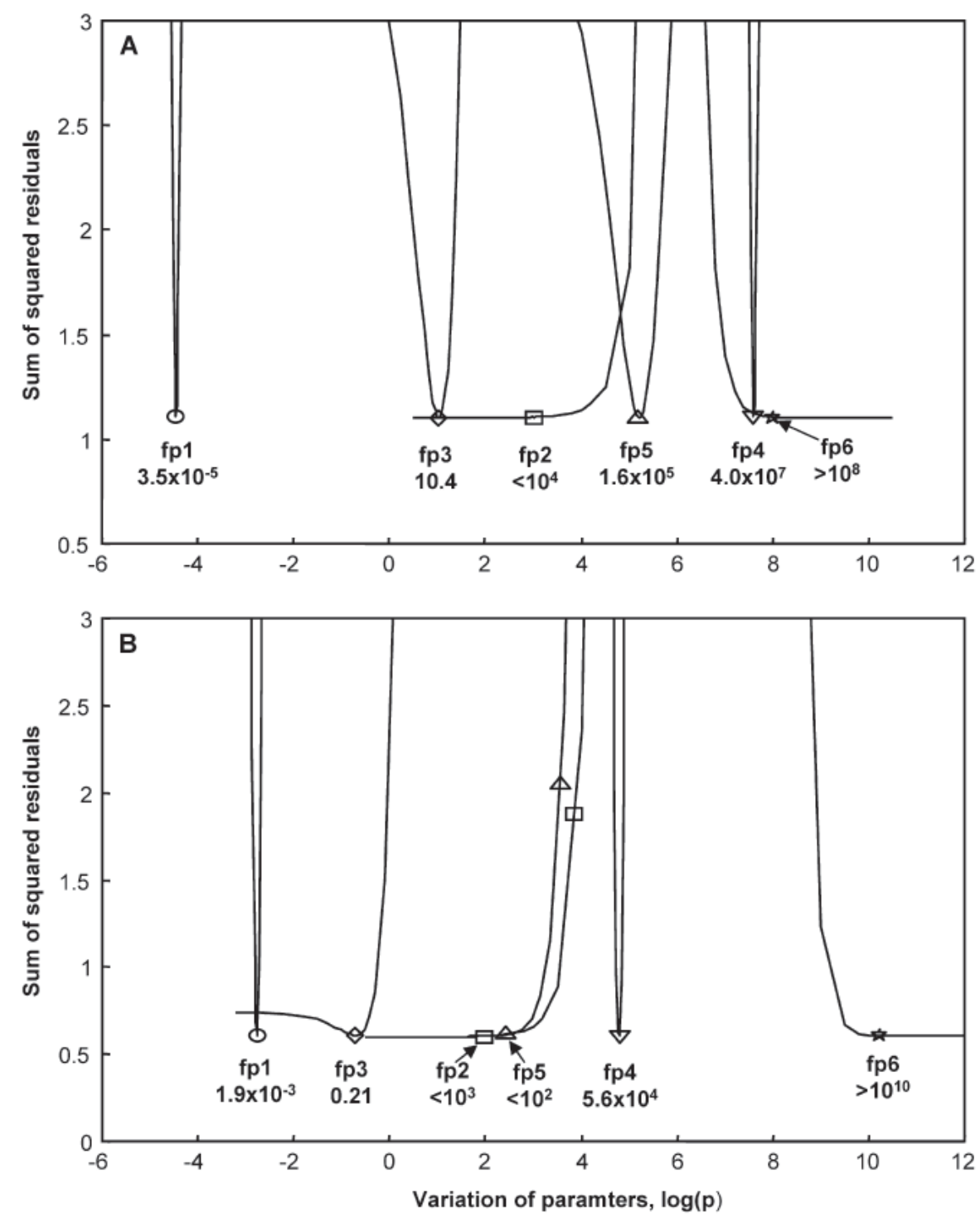

Figure 7. Sum of the squared residuals between model and data as a function of varying each single fitting parameter while keeping the other parameters at their optimized values. fp stands for fitting parameter, and the values of fp1-fp6 correspond to those in Table 2 . A: LMW DOM from site P3; B: LMW DOM from site M4.

$\left(\mathrm{k}_{\mathrm{cat}}\right)$ of $\mathrm{O}_{2}^{--}$in the presence of organic copper complexes. This value is the average of the range of $\mathrm{k}_{\text {cat }}$ determined in coastal water samples (Voelker et al., 2000). Measured $\mathrm{Cu}$ concentrations in the LMW DOM samples from sites $\mathrm{P} 3$ and $\mathrm{M} 4$ were $\sim 2 \mathrm{nM}$ and $\sim 8 \mathrm{nM}$, respectively. The rate constant $\mathrm{k}_{\text {other }}$ was estimated from Figure 2 in Goldstone and Voelker (2000) at the corresponding absorption coefficients $\left(\alpha_{300}\right)$ of the LMW DOM samples from sites P3 and M4. Hence the values for the overall rate constant, $k_{12}$, can only be considered as very rough estimates.

With these values (Table 2), excellent agreement between the mathematical simulation (solid lines in Figs. 5 and 6) and the experimental data was obtained for the $\mathrm{Fe}$ (II) concentration during irradiation and after the light source was turned off, both for the P3 and M4 LMW DOM samples. The model also was able to simulate reasonable well the $\mathrm{H}_{2} \mathrm{O}_{2}$ concentration during irradiation (Figs. 5 and 6), although only initially with the LMW DOM sample from site P3 (Fig. 5). Figure 7 shows the sum of the squared residuals between model and data as a function of varying each single fitting parameter while keeping the other parameters at their optimized values. Some parameters are well defined while others can be varied over large ranges without compromising the agreement between model and data. The parabolic curves in Figure 7 would become broader if all other parameters would be optimized again for each variation of each single parameter. Since this type of variation is computationally too time consuming, it was done only for some 
values of the critical parameter fp2 (reduction of $\mathrm{Fe}(\mathrm{III})$ by $\mathrm{O}_{2}^{--}$, see also below).

In the LMW sample from site $\mathrm{P} 3$ the rate constants of oxidation of $\mathrm{Fe}(\mathrm{II})$ bound to ligand $\mathrm{L}, \mathrm{Fe}^{\mathrm{II}} \mathrm{L}$, by $\mathrm{O}_{2}, \mathrm{O}_{2}^{--}$, and $\mathrm{H}_{2} \mathrm{O}_{2}$ (fp3, fp4, and fp5, respectively) are in the same range as those of oxidation of inorganic $\mathrm{Fe}(\mathrm{II})$ species by these oxidants (Table 2). In the LMW DOM sample from site M4, however, the rate constants of oxidation of $\mathrm{Fe}^{\mathrm{II}} \mathrm{L}$ by $\mathrm{O}_{2}, \mathrm{O}_{2}^{-}$, and $\mathrm{H}_{2} \mathrm{O}_{2}$ (fp3, fp 4 , and $\mathrm{fp} 5$, respectively) are orders of magnitude smaller, as compared to the corresponding rate constants of inorganic Fe(II) oxidation (Table 2). Hence the results of this model are consistent with our hypothesis that the slow decay of the Fe(II) concentration in the LMW DOM samples from Murtensee is due to stabilization of $\mathrm{Fe}$ (II) by a ligand that forms more stable complexes with Fe(II) than with Fe(III), although they do not prove it.

Another striking result from the simulation of the experimental data with kinetic modeling is the following: The rate constants of reduction of $\mathrm{Fe}$ (III) by $\mathrm{O}_{2}^{*^{-}}$(fp2) turned out to be orders of magnitude smaller than the reported rate constant of reduction of inorganic $\mathrm{Fe}(\mathrm{III})$ by $\mathrm{O}_{2}^{\circ-}$ above $\mathrm{pH}$ 6, which is $1.50 \times 10^{8} \mathrm{M}^{-1} \mathrm{~s}^{-1}$ (Rush and Bielski, 1985). Even with a re-optimization of all other parameters, fp2 could not be increased to above $10^{4} \mathrm{M}^{-1}$ $\mathrm{s}^{-1}$ (LMW DOM sample from site P3) and above $10^{3} \mathrm{M}^{-1}$ $\mathrm{s}^{-1}$ (LMW DOM sample from site M4) without a significant increase of the sum of squared residuals. Note that in our model, Fe(III) stands for total iron initially present in the LMW DOM samples from sites P3 and M4, and it is likely that $>99 \%$ is present in the form of organic $\mathrm{Fe}(\mathrm{III})$ complexes (e.g., Powell and Donat, 2001; Rue and Bruland, 1995; Rue and Bruland, 1997; van den Berg, 1995; Wu and Luther, 1995).

Regarding reduction of organically bound Fe(III) by $\mathrm{O}_{2}^{--}$, second-order rate constants with well defined Fe(III) complexes have been reported (Bielski et al., 1985; Buettner et al., 1983; Butler and Halliwell, 1982; Rose and Waite, 2005). Measurements of the $\mathrm{O}_{2}^{--}$decay in the presence of $\mathrm{Fe}$ (III) complexes yielded $9.3 \pm 0.2 \times 10^{3} \mathrm{M}^{-1} \mathrm{~s}^{-1}$ and $1.9 \pm 0.2 \times 10^{5} \mathrm{M}^{-1} \mathrm{~s}^{-1}$ for the second-order rate constant of reaction of $\mathrm{O}_{2}^{--}$with $\mathrm{Fe}(\mathrm{III})$ bound to desferrioxamine B (DFB) and to salicylate, respectively, at $\mathrm{pH} 8.1$ (Rose and Waite, 2005). Employing pulse radiolysis, Butler and Halliwell (1982) determined the second-order rate constant of reaction of $\mathrm{O}_{2}^{--}$with $\mathrm{Fe}^{\text {IIII-EDTA }}{ }^{-}$to be $3 \pm 0.5$ $\times 10^{5} \mathrm{M}^{-1} \mathrm{~s}^{-1}$ at $\mathrm{pH}$ 8. These authors also measured rate constants of reaction of $\mathrm{O}_{2}^{--}$with $\mathrm{Fe}(\mathrm{III})$ bound to ligands other than EDTA. They found that complexes of Fe(III) with diethylenetriaminepentaacetic acid (DETAPAC), bathophenanthroline, and desferrioxamine (DFB) reacted with $\mathrm{O}_{2}^{-}$at much lower, "perhaps insignificant rates". They stress that their determined rate constants of reaction of $\mathrm{O}_{2}^{--}$with $\mathrm{Fe}$ (III) bound to ligands other than EDTA only can be considered as upper limits (e.g., $\mathrm{k}=<2 \times 10^{5}$
$\mathrm{M}^{-1} \mathrm{~s}^{-1}$ for the reduction of $\mathrm{Fe}(\mathrm{III})-\mathrm{DFB}$ by $\mathrm{O}_{2}^{--}$at $\mathrm{pH}$ 7.0). According to Buettner and coworkers (1983), who also used pulse radiolysis, the upper limit of the second-order rate constant of reduction of $\mathrm{Fe}(\mathrm{III})$-DETAPAC by $\mathrm{O}_{2}^{--}$is $<10^{4} \mathrm{M}^{-1} \mathrm{~s}^{-1}$ at $\mathrm{pH}$ 8.0. These authors state that thermodynamics does not appear to govern observed rates of reduction of organic $\mathrm{Fe}(\mathrm{III})$ complexes by $\mathrm{O}_{2}^{--}$, but rather steric factors. On the other hand, Rose and Waite (2005) found that the rate of reduction of organically complexed $\mathrm{Fe}(\mathrm{III})$ by $\mathrm{O}_{2}^{--}$generally depended on the stability of the complex.

The values determined with our model as best fits for the second-order rate constant of reaction of $\mathrm{O}_{2}^{--}$with Fe(III) in the P3 LMW DOM and M4 LMW DOM samples (fp2 in Table 2 and in Fig. 7) are $<10^{4}$ and $<10^{3} \mathrm{M}^{-1}$ $\mathrm{s}^{-1}$, respectively and hence not too far from reported rate constants of reaction of $\mathrm{O}_{2}^{--}$with well-defined $\mathrm{Fe}(\mathrm{III})$ complexes (see above). In sunlit surface waters LMW compounds likely consist in part of siderophores (e.g., Powell and Wilson-Finelli, 2003) that are strong chelators of Fe(III) (Albrecht-Gary and Crumbliss, 1998; Witter et al., 2000). The purpose of the simulation of our experimental data with mathematical kinetic modeling was not to determine rate constants that could be generalized but to test hypotheses. Our modeling results are consistent with, but do not prove, that the main pathway of $\mathrm{Fe}(\mathrm{III})$ reduction in the LMW DOM samples from sites P3 and M4 is photolysis of $\mathrm{Fe}(\mathrm{III})$ complexes (and not reduction of $\mathrm{Fe}(\mathrm{III})$ by $\mathrm{O}_{2}^{-}$).

\section{Effect of DOM origin on $\mathrm{Fe}$ (II) steady-state concentrations}

Figure $8 \mathrm{~A}$ shows the percentage of $[\mathrm{Fe}(\mathrm{II})]_{\mathrm{ss}}$ from total dissolved iron in HMW DOM fractions gained from water samples collected at sites with different salinity during the Navicula cruise (samples from sites N1-N5, see Table 1 and Fig. $2 \mathrm{C}$ ). The percentage of [Fe(II) $]_{\mathrm{ss}}$ from total dissolved iron was higher in the HMW DOM samples with a higher proportion of freshwater, and was higher in the River Waal than in the River Scheldt water samples. As also observed for the sea- and freshwater samples from sites P1-P5 and M1-M4, respectively, [Fe(II) $]_{\mathrm{ss}}$ is not primarily controlled by total dissolved iron concentrations. A similar pattern as shown in Figure 8A is observed for [Fe(II) $]_{\mathrm{ss}}$, normalized to $1 \mathrm{mg} \mathrm{C} \mathrm{L}^{-1}$ (Fig. 8B). Obviously, $[\mathrm{Fe}(\mathrm{II})]_{\mathrm{ss}}$ depends on the type of HMW organic compounds present. In the River Scheldt and River Waal (sites $\mathrm{N} 1$ and $\mathrm{N} 2$, respectively), these compounds are likely to be terrestrially derived, whereas in the North Sea (sites N4 and N5) autochthonous HMW DOM is predominant. At site N3 (salinity 9.6\%), HMW DOM is probably a mixture of terrestrial and algal-derived compounds. Gaberell and coworkers (2003) found significantly higher rates of $\mathrm{Cr}(\mathrm{VI})$ reduction with $\mathrm{DOM}$ de- 

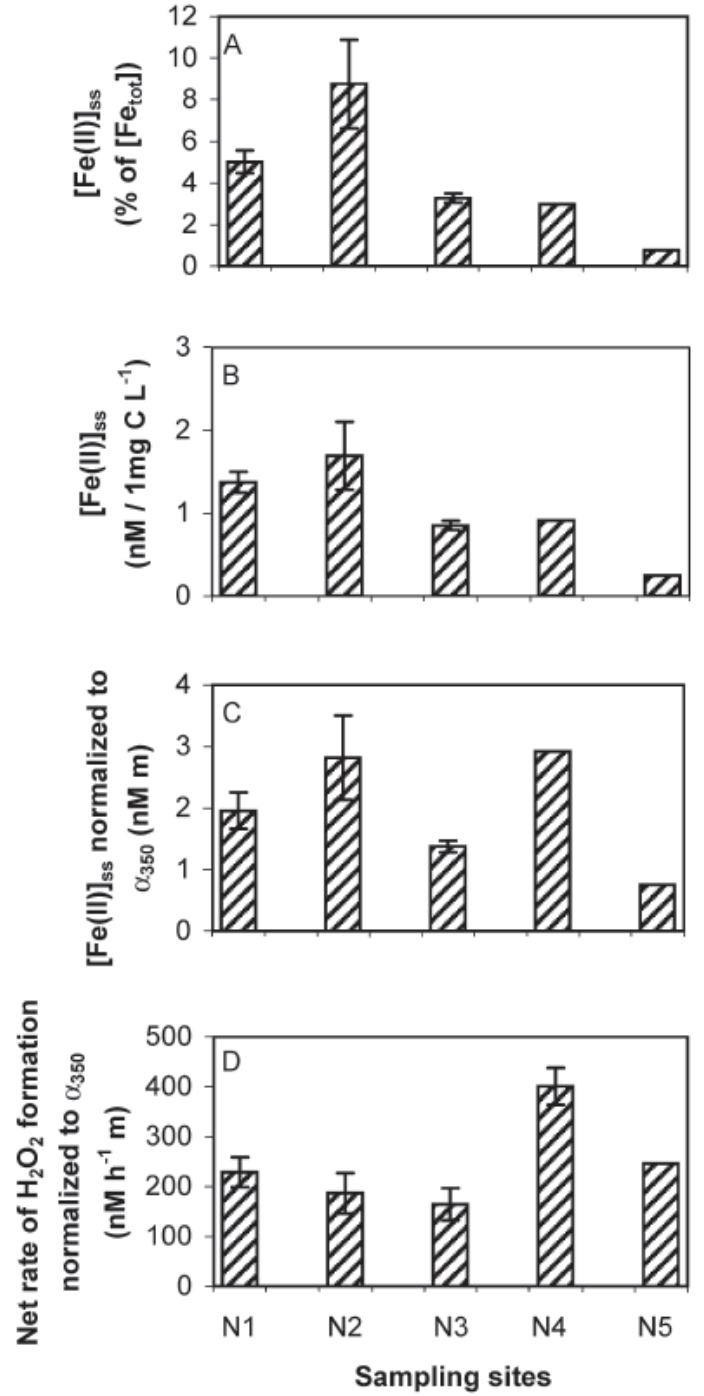

Figure 8. Steady-state concentrations of $\mathrm{Fe}(\mathrm{II})$ as percentage of total dissolved iron (A), normalized to $1 \mathrm{mg} \mathrm{C} \mathrm{L}^{-1}(\mathrm{~B})$, and normalized to $\alpha_{350}(\mathrm{C})$, and net rate of $\mathrm{H}_{2} \mathrm{O}_{2}$ formation, normalized to $\alpha_{350}$ (D) during irradiation with simulated sunlight $\left(\mathrm{I}_{0} \sim 1.2 \mathrm{~kW} \mathrm{~m}^{-2}\right)$ of HMW DOM $(\mathrm{pH}=8.2)$ from sites N1-N5. The HMW DOM powders were dissolved in MQ-UV water yielding a DOC concentration of approximately $2 \mathrm{mg} \mathrm{L}^{-1}$ in each sample. Data represent the mean of 2-3 measurements; vertical bars indicate the mean deviation.

rived from terrestrial sources than with predominantly autochthonous materials even if additional iron was added to the latter. Based on their results, these authors hypothesize that the rate-determining step in $\mathrm{Cr}(\mathrm{VI})$ reduction is light-induced formation of $\mathrm{Fe}(\mathrm{II})$, either through photolysis of $\mathrm{Fe}$ (III) complexes or via reduction of $\mathrm{Fe}(\mathrm{III})$ by $\mathrm{O}_{2}^{--}$or other intermediates formed in photochemical reactions after light absorption of DOM (see Fig. 1). Gaberell and coworkers (2003) also found that the terrestrially derived DOM samples exhibited a higher percentage of aromaticity and higher molar absorption coefficients at $280 \mathrm{~nm}$ than the algal derived DOM samples and, therefore, were photochemically more reactive in $\mathrm{Cr}(\mathrm{VI})$ reduction.

The Fe(II) steady-state concentration in the HMW DOM sample from site N4 (River Rhine estuary, see Fig. 2C), normalized to both total dissolved iron and $1 \mathrm{mg} \mathrm{C} \mathrm{L}{ }^{-1}$, was almost identical to that in the HMW DOM sample from site N3 (north of N4 in the River Rhine estuary, see Fig. 2C) and considerably higher than that in the HMW DOM sample from site N5 (see Fig. 2C). Furthermore, approximately equal $\mathrm{Fe}$ (II) steady-state concentrations, normalized to the decadic absorption coefficient at $350 \mathrm{~nm}\left(\alpha_{350}\right.$, unit $\left.\mathrm{m}^{-1}\right)$ were measured in the HMW DOM samples from sites N4 and N2 (Fig. 8C), where site N2 is the River Waal site. Interestingly, the net rate of $\mathrm{H}_{2} \mathrm{O}_{2}$ formation, normalized to $\alpha_{350}$, was highest in the HMW DOM sample from N4 (Fig. 8D). The elucidation of causes for this higher photochemical reactivity of HMW DOM compounds from site N4, compared to HMW DOM compounds from the other sampling sites of the Navicula cruise, would involve chemical characterization of these compounds (Kaiser et al., 2003; Schwede-Thomas et al., 2005), which was outside the scope of this study.

\section{Conclusions}

The main results of this study can be summarized as follows: (i) In the studied sea- and freshwater samples, LMW DOM compounds exhibited a higher photochemical reactivity towards Fe(II) formation than HMW DOM compounds. This result led us to the hypothesis that the main pathway of $\mathrm{Fe}$ (III) reduction in these water samples is photolysis of $\mathrm{Fe}$ (III) complexes (and not reduction of $\mathrm{Fe}(\mathrm{III})$ by $\left.\mathrm{O}_{2}^{-}\right)$and occurs more readily if $\mathrm{Fe}(\mathrm{III})$ is bound to LMW organic ligands, as compared to HMW ligands. (ii) We hypothesize that the slow decay of the Fe(II) concentration after irradiation of the LMW water samples from Murtensee may be due to stabilization of Fe(II) by a ligand that forms more stable complexes with $\mathrm{Fe}(\mathrm{II})$ than with $\mathrm{Fe}(\mathrm{III})$. (iii) The simulation of the experimental data obtained with the LMW DOM samples from sites P3 and M4 with mathematical kinetic modeling is in agreement with our hypotheses presented above under (i) and (ii). (iv) The origin and thus the chemical composition of HMW DOM compounds determined their photoreactivity towards $\mathrm{Fe}$ (II) formation in the "river-to-ocean" water samples, confirming the findings by Gaberell and coworkers (2003).

The assessment of the environmental factors that determine $[\mathrm{Fe}(\mathrm{II})]_{\mathrm{ss}}$ is key since $\mathrm{Fe}(\mathrm{II})$ is an utmost important intermediate species in sunlit surface waters, not only regarding the bioavailability of iron but also the role of $\mathrm{Fe}(\mathrm{II})$ as an electron donor. One of the key redox reactions involving $\mathrm{Fe}(\mathrm{II})$ is the Fenton reaction yielding the hydroxyl radical. The oxidation of organic and inorganic pollutants by $\mathrm{HO}^{*}$ may not always be beneficial but may 
increase the toxicity of pollutants as in the case of $\mathrm{Hg}_{\mathrm{ac}}^{0}$ (Lalonde et al., 2004). In addition, HO can damage cellular components such as proteins, lipids, and nucleic acids (Lupinkova and Komenda, 2004). Kaiser and Sulzberger (2004) observed a short-term $(1 \mathrm{~h})$ decrease in bacterial utilization of irradiated high-molecular-weight, low-molecular-weight, hydrophobic, and hydrophilic DOM fractions by up to $80 \%$, compared with the uptake of the corresponding non-irradiated fractions. Based on experiments with the addition of ROS scavengers and on measured $\mathrm{Fe}$ (II) formation during irradiation, these authors hypothesize that $\mathrm{HO}^{\circ}$, formed in the Fenton reaction, was responsible for the inhibition of bacterial utilization of irradiated high-molecular-weight DOM.

\section{Acknowledgments}

We acknowledge the Swiss Government (Bundesamt für Bildung und Wissenschaft) for the financial support of this project, which was part of the EU-Project COMET (Composition of Dissolved Organic Matter and its Interactions with Metals and Ultraviolet Radiation in RiverOcean Systems: Impact on the Microbial Food Web). We thank Rainer Amon (Alfred Wegener Institute Foundation for Polar and Marine Research (AWI), Bremerhaven, Germany; present address: Texas A\&M University at Galveston, Galveston, Texas, USA) for providing us with the HMW DOM samples from sites N1-N5 and with the DOC data at these sites. We also thank Diane BuergeWeirich and Edith Kaiser (Eawag; present address of Diane Buerge-Weirich: Swiss Federal Research Station for Agroecology and Agriculture (FAL), Zürich, Switzerland) for their help before and during the Pelagia cruise, and for many fruitful discussions. Last but not least we would like to acknowledge D. Whitney King (Colby College, Waterville, Maine, USA) for his help with the evaluation of rate constants of inorganic Fe(II) oxidation.

\section{References}

Albrecht-Gary, A. M. and A. L. Crumbliss, 1998. Coordination chemistry of siderophores: Thermodynamics and kinetics of iron chelation and release. In: A. Sigel and H. Sigel (eds.), Iron Transport and Storage in Microorganisms, Plants and Animals, Metal Ions in Biological Systems, Marcel Dekker, New York, pp. 239-327.

Aldrich, A. P. and C. M. G. van den Berg, 1998. Determination of iron and its redox speciation in seawater using catalytic cathodic stripping voltammetry. Electroanalysis 10: 369-373.

Anderson, M. A. and F. M. M. Morel, 1982. The influence of aqueous iron chemistry on the uptake of iron by the coastal diatom Thalassiosira weissflogii. Limnol. Oceanogr. 27: 789-813.

Barbeau, K., E. L. Rue, K. W. Bruland and A. Butler, 2001. Photochemical cycling of iron in the surface ocean mediated by microbial iron(III)-binding ligands. Nature 413: 409-413.
Barbeau, K., E. L. Rue, C. G. Trick, K. T. Bruland and A. Butler, 2003. Photochemical reactivity of siderophores produced by marine heterotrophic bacteria and cyanobacteria based on characteristic Fe(III) binding groups. Limnol. Oceanogr. 48: 10691078.

Barbeau, K., G. P. Zhang, D. H. Live and A. Butler, 2002. Petrobactin, a photoreactive siderophore produced by the oil-degrading marine bacterium Marinobacter hydrocarbonoclasticus. J. Am. Chem. Soc. 124: 378-379.

Benner, R., B. Biddanda, B. Black and M. McCarthy, 1997. Abundance, size distribution, and stable carbon and nitrogen isotopic compositions of marine organic matter isolated by tangentialflow ultrafiltration. Mar. Chem. 57: 243-263.

Benner, R. and M. Strom, 1993. A critical evaluation of the analytical blank associated with DOC measurements by high-temperature catalytic oxidation. Mar. Chem. 41: 153-160.

Bielski, B. H. J., D. E. Cabelli and R. L. Arudi, 1985. Reactivity of $\mathrm{HO}_{2} / \mathrm{O}_{2}^{-}$radicals in aqueous solution. J. Phys. Chem. Ref. Data 14: $1060-1063$.

Blough, N. V. and R. G. Zepp, 1995. Reactive oxygen species in natural waters. In: C. S. Foote, J. S. Valentine, A. Greenberg and J. F. Liebman (eds.), Active Oxygen Species in Chemistry, Blackie Academic and Professional, New York, pp. 280-333.

Borer, P. M., B. Sulzberger, P. Reichard and M. S. Kraemer, 2005. Effect of siderophores on the light-induced dissolution of colloidal iron(III) (hydr)oxides. Mar. Chem. 93: 179-193.

Braun, W., J. T. Herron and D. K. Kahaner, 1988. Acuchem: a computer program for modeling complex chemical reaction systems. Int. J. Chem. Kinet. 20: 51-62.

Bruland, K. W., E. L. Rue, J. R. Donat, S. A. Skrabal and J. W. Moffett, 2000. Intercomparison of voltammetric techniques to determine the chemical speciation of dissolved copper in a coastal seawater sample. Anal. Chim. Acta 405: 99-113.

Buettner, G. R., T. P. Doherty and L. K. Patterson, 1983. The kinetics of the reaction of superoxide radical with $\mathrm{Fe}$ (III) complexes of EDTA, DETAPAC and HEDTA. FEBS Lett. 158: $143-146$.

Butler, A., 1998. Acquisition and utilization of transition metal ions by marine organisms. Science 281: 207-210.

Butler, J. and B. Halliwell, 1982. Reaction of iron-EDTA chelates with the superoxide radical. Arch. Biochem. Biophys. 218: 174 178.

Emmenegger, L., D. W. King, L. Sigg and B. Sulzberger, 1998. Oxidation kinetics of $\mathrm{Fe}(\mathrm{II})$ in a eutrophic Swiss lake. Environ. Sci. Technol. 32: 2990-2996.

Emmenegger, L., R. Schönenberger, L. Sigg and B. Sulzberger, 2001. Light-induced redox cycling of iron in circumneutral lakes. Limnol. Oceanogr. 46: 49-61.

Falkowski, P. G., 1997. Evolution of the nitrogen cycle and its influence on the biological sequestration of $\mathrm{CO}_{2}$ in the ocean. Nature 387: 272-275.

Faust, B. C. and R. G. Zepp, 1993. Photochemistry of aqueous iron(III) polycarboxylate complexes - Roles in the chemistry of atmospheric and surface waters. Environ. Sci. Technol. 27: 2517-2522.

Gaberell, M., Y.-P. Chin, S. J. Hug and B. Sulzberger, 2003. Role of dissolved organic matter composition on the photoreduction of $\mathrm{Cr}(\mathrm{VI})$ to $\mathrm{Cr}(\mathrm{III})$ in the presence of iron. Environ. Sci. Technol. 37: 4403-4409.

Gao, H. Z. and R. G. Zepp, 1998. Factors influencing photoreactions of dissolved organic matter in a coastal river of the southeastern United States. Environ. Sci. Technol. 32: 2940 2946.

Goldstone, J. V. and B. M. Voelker, 2000. Chemistry of superoxide radical in seawater: $\mathrm{CDOM}$ associated sink of superoxide in coastal waters. Environ. Sci. Technol. 34: 1043-1048.

Hatchard, C. G. and C. A. Parker, 1956. A new sensitive chemical actinometer II. Potassium ferrioxalate as a standard chemical actinometer. Proc. R. Soc. Lond. Ser. A 235: 518-536. 
Haygood, M. G., P. D. Holt and A. Butler, 1993. Aerobactin production by a planktonic marine Vibrio sp. Limnol. Oceanogr. 38: 1091-1097.

Hug, S. J., H.-U. Laubscher and B. R. James, 1997. Iron(III) catalyzed photochemical reduction of chromium(VI) by oxalate and citrate in aqueous solutions. Environ. Sci. Technol. 31: 160 170.

Hutchins, D. A., A. E. Witter, A. Butler and G. W. Luther, 1999. Competition among marine phytoplankton for different chelated iron species. Nature 400: $858-861$.

Jones, G. J., B. P. Palenik and F. M. M. Morel, 1987. Trace metal reduction by phytoplankton: The role of plasmalemma redox enzymes. J. Phycol. 23: 237-244.

Kaiser, E., A. J. Simpson, K. J. Dria, B. Sulzberger and P. G. Hatcher, 2003. Solid-state and multidimensional solutionstate NMR of solid phase extracted and ultrafiltered riverine dissolved organic matter. Environ. Sci. Technol. 37: 29292935.

Kaiser, E. and B. Sulzberger, 2004. Phototransformation of riverine dissolved organic matter (DOM) in the presence of abundant iron: Effect on DOM bioavailability. Limnol. Oceanogr. 49: $540-554$.

Kieber, R. J. and G. R. Helz, 1992. Indirect photoreduction of aqueous chromium(VI). Environ. Sci. Technol. 26: 307-312.

King, D. W., 1998. Role of carbonate speciation on the oxidation rate of Fe(II) in aquatic systems. Environ. Sci. Technol. 32: 2997-3003.

King, D. W. and R. Farlow, 2000. Role of carbonate speciation on the oxidation of $\mathrm{Fe}(\mathrm{II})$ by $\mathrm{H}_{2} \mathrm{O}_{2}$. Mar. Chem. 70: 201-209.

King, D. W., H. A. Lounsbury and F. J. Millero, 1995. Rates and mechanism of Fe(II) oxidation at nanomolar total iron concentrations. Environ. Sci. Technol. 29: 818-824.

Kuma, K., S. Nakabayashi, Y. Suzuki, I. Kudo and K. Matsunaga, 1992. Photo-reduction of $\mathrm{Fe}(\mathrm{III})$ by dissolved organic substances and existence of $\mathrm{Fe}(\mathrm{II})$ in seawater during spring blooms. Mar. Chem. 37: 15-27.

Lalonde, J. D., M. Amyot, J. Orvoine, F. M. M. Morel, J. C. Auclair and P. A. Ariya, 2004. Photoinduced oxidation of $\mathrm{Hg}^{0}(\mathrm{aq})$ in the waters from the St. Lawrence estuary. Environ. Sci. Technol. 38: $508-514$.

Liang, L. Y., J. A. McNabb, J. M. Paulk, B. H. Gu and J. F. McCarthy, 1993. Kinetics of $\mathrm{Fe}(\mathrm{II})$ oxygenation at low partial pressure of oxygen in the presence of natural organic matter. Environ. Sci. Technol. 27: 1864-1870.

Lupinkova, L. and J. Komenda, 2004. Oxidative modifications of the Photosystem II D1 protein by reactive oxygen species: From isolated protein to cyanobacterial cells. Photochem. Photobiol. 79: 152-162.

Maldonado, M. T. and N. M. Price, 1999. Utilization of iron bound to strong organic ligands by plankton communities in the subarctic Pacific Ocean. Deep-Sea Res. Part II-Top. Stud. Oceanogr. 46: 2447-2473.

Maldonado, M. T. and N. M. Price, 2001. Reduction and transport of organically bound iron by Thalassiosira oceanica (Bacillariophyceae). J. Phycol. 37: 298-309.

Miles, C. J. and P. L. Brezonik, 1981. Oxygen consumption in humic-colored waters by a photochemical ferrous-ferric catalytic cycle. Environ. Sci. Technol. 15: 1089-1095.

Miller, W. L. and D. R. Kester, 1988. Hydrogen peroxide measurement in seawater by (p-hydroxyphenyl)acetic acid dimerization. Anal. Chem. 60: 2711-2715.

Miller, W. L., D. W. King, J. Lin and D. R. Kester, 1995. Photochemical redox cycling of iron in coastal seawater. Mar. Chem. 50: $63-77$.

Mills, M. M., C. Ridame, M. Davey, J. La Roche and R. J. Geider, 2004. Iron and phosphorus co-limit nitrogen fixation in the eastern tropical North Atlantic. Nature 429: 292-294.

Morel, F. M. M. and N. M. Price, 2003. The biogeochemical cycles of trace metals in the oceans. Science 300: 944-947.
Powell, R. T. and J. R. Donat, 2001. Organic complexation and speciation of iron in the South and Equatorial Atlantic. Deep-Sea Res. Part II-Top. Stud. Oceanogr. 48: 2877-2893.

Powell, R. T. and A. Wilson-Finelli, 2003. Photochemical degradation of organic iron complexing ligands in seawater. Aquat. Sci. 65: $367-374$.

Pullin, M. J. and S. E. Cabaniss, 2003. The effects of $\mathrm{pH}$, ionic strength, and iron-fulvic acid interactions on the kinetics of non-photochemical iron transformations. I. Iron(II) oxidation and iron(III) colloid formation. Geochim. Cosmochim. Acta 67: 4067-4077.

Reid, R. T. and A. Butler, 1991. Investigation of the mechanism of iron acquisition by the marine bacterium Alteromonas luteoviolaceus: Characterization of siderophore production. Limnol. Oceanogr. 36: 1783-1792.

Rose, A. L. and T. D. Waite, 2002. Kinetic model for Fe(II) oxidation in seawater in the absence and presence of natural organic matter. Environ. Sci. Technol. 36: 433-444.

Rose, A. L. and T. D. Waite, 2003a. Predicting iron speciation in coastal waters from the kinetics of sunlight-mediated iron redox cycling. Aquat. Sci. 65: 375-383.

Rose, A. L. and T. D. Waite, 2003b. Effect of dissolved natural organic matter on the kinetics of ferrous iron oxygenation in seawater. Environ. Sci. Technol. 37: 4877-4886.

Rose, A. L. and T. D. Waite, 2005. Reduction of organically complexed ferric iron by superoxide in a simulated natural water. Environ. Sci. Technol. 39: 2645-2650.

Rue, E. L. and K. W. Bruland, 1995. Complexation of iron(III) by natural organic ligands in the Central North Pacific as determined by a new competitive ligand equilibration adsorptive cathodic stripping voltammetric method. Mar. Chem. 50: 117138.

Rue, E. L. and K. W. Bruland, 1997. The role of organic complexation on ambient iron chemistry in the equatorial Pacific Ocean and the response of a mesoscale iron addition experiment. Limnol. Oceanogr. 42: 901-910.

Rush, J. D. and B. H. J. Bielski, 1985. Pulse radiolysis studies of the reactions of $\mathrm{HO}_{2} / \mathrm{O}_{2}^{-}$with ferric ions and its implication on the occurrence of the Haber-Weiss reaction. J. Phys. Chem. 89: 5062-5066.

Santana-Casiano, J. M., M. González-Dávila and F. J. Millero, 2004. The oxidation of $\mathrm{Fe}(\mathrm{II})$ in $\mathrm{NaCl}-\mathrm{HCO}_{3}^{-}$and seawater solutions in the presence of phthalate and salicylate ions: a kinetic model. Mar. Chem. 85: 27-40.

Schulz, K. G., I. Zondervan, L. J. A. Gerringa, K. R. Timmermans, M. J. W. Veldhuis and U. Riebesell, 2004. Effect of trace metal availability on coccolithophorid calcification. Nature 430: 673-676.

Schwede-Thomas, S. B., Y.-P. Chin, K. J. Dria, P. G. Hatcher, E. Kaiser and B. Sulzberger, 2005. Characterizing the properties of dissolved organic matter isolated by XAD and C-18 solid phase extraction and ultrafiltration. Aquat. Sci. 67: 61-71.

Sedlak, D. L. and J. Hoigné, 1993. The role of copper and oxalate in the redox cycling of iron in atmospheric waters. Atmospheric Environment 27A: 2173-2185.

Siffert, C. and B. Sulzberger, 1991. Light-induced dissolution of hematite in the presence of oxalate: A case study. Langmuir 7: $1627-1634$.

Somville, M. and N. Depauw, 1982. Influence of temperature and river discharge on water quality of the Western Scheldt Estuary. Water Res. 16: 1349-1356.

Soria-Dengg, S. and U. Horstmann, 1995. Ferrioxamine-B and ferrioxamine-E as iron sources for the marine diatom Phaeodactylum tricornutum. Mar. Ecol., Prog. Ser. 127: 269-277.

Southworth, B. A. and B. M. Voelker, 2003. Hydroxyl radical production via the photo-Fenton reaction in the presence of fulvic acid. Environ. Sci. Technol. 37: 1130-1136.

Sunda, W. G., 1991. Trace metal interactions with marine phytoplankton. Biol. Oceanogr. 6: 411-442. 
Suter, D., C. Siffert, B. Sulzberger and W. Stumm, 1988. Catalytic dissolution of iron(III) (hydr)oxides by oxalic acid in the presence of Fe(II). Naturwissenschaften 75: 571-573.

Suzuki, Y., K. Kuma, I. Kudo, K. Hasebe and K. Matsunaga, 1992. Existence of stable $\mathrm{Fe}$ (II) complex in oxic river water and its determination. Water Res. 26: 1421-1424.

Theis, T. L. and P. C. Singer, 1974. Complexation of iron(II) by organic matter and its effect on iron(II) oxygenation. Environ. Sci. Technol. 8: 569-573.

Tortell, P. D., M. T. Maldonado, J. Granger and N. M. Price, 1999. Marine bacteria and biogeochemical cycling of iron in the oceans. FEMS Microbiol. Ecol. 29: 1-11.

Van den Berg, C. M. G., 1984. Determination of the complexing capacity and conditional stability constants of complexes of copper(II) with natural organic ligands in seawater by cathodic stripping voltammetry of copper catechol complex ions. Mar. Chem. 15: 1-18.

Van den Berg, C. M. G., 1995. Evidence for organic complexation of iron in seawater. Mar. Chem. 50: 139-157.

Villinski, J. E., J. E. Saiers and M. H. Conklin, 2003. The effects of reaction-product formation on the reductive dissolution of $\mathrm{MnO}_{2}$ by Fe(II). Environ. Sci. Technol. 37: 5589-5596.

Voelker, B. M. and M. B. Kogut, 2001. Interpretation of metal speciation data in coastal waters: the effects of humic substances on copper binding as a test case. Mar. Chem. 74: 303318.

Voelker, B. M., F. M. M. Morel and B. Sulzberger, 1997. Iron redox cycling in surface waters: Effects of humic substances and light. Environ. Sci. Technol. 31: 1004-1011.

Voelker, B. M. and D. L. Sedlak, 1995. Iron reduction by photoproduced superoxide in seawater. Mar. Chem. 50: 93-102.

Voelker, B. M., D. L. Sedlak and O. C. Zafiriou, 2000. Chemistry of superoxide radical in seawater: Reactions with organic $\mathrm{Cu}$ complexes. Environ. Sci. Technol. 34: 1036-1042.
Voelker, B. M. and B. Sulzberger, 1996. Effects of fulvic acid on $\mathrm{Fe}(\mathrm{II})$ oxidation by hydrogen peroxide. Environ. Sci. Technol. 30: 1106-1114.

Weger, H. G., 1999. Ferric and cupric reductase activities in the green alga Chlamydomonas reinhardtii: experiments using ironlimited chemostats. Planta 207: 377-384.

Weger, H. G., J. K. Middlemiss and C. D. Petterson, 2002. Ferric chelate reductase activity as affected by the iron-limited growth rate in four species of unicellular green algae (Chlorophyta). J. Phycol. 38: 513-519.

Welch, K. D., T. Z. Davis and S. D. Aust, 2002. Iron autoxidation and free radical generation: Effects of buffers, ligands, and chelators. Arch. Biochem. Biophys. 397: 360-369.

White, E. M., P. P. Vaughan and R. G. Zepp, 2003. Role of the photoFenton reaction in the production of hydroxyl radicals and photobleaching of colored dissolved organic matter in a coastal river of the southeastern United States. Aquat. Sci. 65: 402-414.

Wilhelm, S. W. and C. G. Trick, 1994. Iron-limited growth of cyanobacteria: Multiple siderophore production is a common response. Limnol. Oceanogr. 39: 1979-1984.

Witter, A. E., D. A. Hutchins, A. Butler and G. W. Luther, 2000. Determination of conditional stability constants and kinetic constants for strong model Fe-binding ligands in seawater. Mar. Chem. 69: 1-17.

Wu, J. F. and G. W. Luther, 1995. Complexation of Fe(III) by natural organic ligands in the Northwest Atlantic Ocean by a competitive ligand equilibration method and a kinetic approach. Mar. Chem. 50: 159-177.

Zafiriou, O. C., 1990. Chemistry of superoxide ion-radical $\left(\mathrm{O}_{2}^{-}\right)$in seawater. I. $p K_{\mathrm{asw}}^{*}(\mathrm{HOO})$ and uncatalyzed dismuation kinetics studied by pulse radiolysis. Mar. Chem. 30: 31-43.

Zafiriou, O. C., B. M. Voelker and D. L. Sedlak, 1998. Chemistry of the superoxide radical $\left(\mathrm{O}_{2}^{-}\right)$in seawater: Reactions with inorganic copper complexes. J. Phys. Chem. A 102: 5693-5700. 